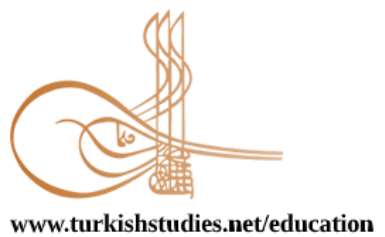

Turkish Studies - Educational Sciences

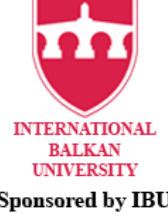

Research Article / Araştırma Makalesi

\title{
Korunmaya Muhtaç Öğrencilerin Öğrenme ve Öğretme Sürecinde Karşılaştıkları Sorunların Öğretmen Görüşlerine Göre İncelenmesi*
}

\author{
Investtgatıng The Problems According To Teachers View Which Encountered By The Students In \\ Need Of Protection During Learning And Teaching Process
}

\author{
Murat Başar $^{* *}$ - Muhammed Mustafa Özbek ${ }^{* *}$
}

\begin{abstract}
This study, which aims to examine the problems faced by the students in state protection at the elementary school level during the learning and teaching process according to the opinions of the teachers, was designed according to the descriptive survey model. It is thought that the single nested pattern, one of the qualitative research methods, is suitable for the study. The study group of the research consisted of 18 teachers from three different schools, in different classrooms, who were interviewed by the students in state protection. Eight of the teachers in the study group are men and women are teachers. The opinions of the teachers in the study group formed the data of this study. Data were collected through a semi-structured interview form with teachers. In order to support the teachers' views or to see the difference, 46 hours of observation were made in different areas, in the classroom and in the school garden on different days. In order to obtain data through observation, a semi-structured observation form was used as in the opinions of teachers. Validity and reliability were tried to be increased by comparing the findings obtained from the interviews with the observation data. Interview data and observation findings were found to be compatible. The results supported each other. In the analysis of the data, themes, codes and subcodes were created by making content analysis, and each one was carefully examined and evaluated together with the field experts. Themes formed; "Learning and teaching" are "socializing and adaptation", "problem behaviors" and "suggestions". Codes and subcodes were created in accordance with these themes. It has been determined that the protection of the law was abused by students under state protection. Depending on the protection of the law, it has been determined that students under state protection are not willing to participate in learning and teaching activities. Despite the low school achievements, they were determined to be willing to participate in social activities. It was determined that they tend to disrupt the order of the game during their participation in the social event. Students in state protection need social acceptance. Unconditional acceptance of other student, parent and teacher is needed. It has been determined that the children under state protection interact negatively in each other, both in the school and in
\end{abstract}

\footnotetext{
* Bu çalışma 2019 yılında Doç. Dr. Murat BAŞAR danışmanlığında tamamlanan aynı adlı tezden üretilmiştir.

** Doç. Dr., Uşak Üniversitesi Eğitim Fakültesi, Temel Eğitim Bölümü

Assoc. Prof. Dr. Uşak Universty Faculty of Education, Department of Basic Education

ORCID 0000-0001-6635-4563

murat.basar@usak.edu.tr

** Öğretmen, Aile ve Sosyal Politikalar Bakanlığı

Teacher, Ministry of Family, Labour and Social Services

ORCID 0000-0002-8224-7781

sentooki@gmail.com

Cite as/ Atıf: Başar, M. \& Özbek, M. M. (2020). Korunmaya muhtaç öğrencilerin öğrenme ve öğretme sürecinde karşılaştıkları sorunların öğretmen görüşlerine göre incelenmesi. Turkish Studies - Education, 15(3), 1537-1560. https://dx.doi.org/10.29228/TurkishStudies.41792

Received/Geliş: 16 February/Şubat 2020

Accepted/Kabul: 21 June/Haziran 2020

Checked by plagiarism software

Copyright $\mathbb{C}$ INTAC LTD, Turkey 
the nursery. It has been determined that they tend to exhibit problem behaviors such as aggression towards their friends, not following the rules, escaping from school, and damaging their school belongings. The lack of communication between the schools for students under state protection and the institutions where the students are hosted has been identified.

\section{Structured Abstract: Introduction}

Child in need of protection are those defined with the child Protection Law numbered 5395; as because of having and causing problems decided by social workers investigating them and finally needing special measures by the court. (Juvenile Protection Law, 2005; Article 3). The purpose of this study was to examine the problems which faced students who are in under protection by Child in Need of Protection Law (CNP) during the teaching on learning process based on the teacher's views.

\section{Method}

Descriptive survey model is adopted in this study. single -case embedded design was used as part of qualitative research methods. Participants of the study consisted of 18 teachers, who were in three different schools, working in different classes and interviewed, where the students under the scope of CNP. semistructured interviews were used to collect. Totally 46 hours observation is realized in different classrooms both in classrooms and at school garden. It is benefited from semi-structured observation form in order to getting data via observation. Comparing with observation and findings of interviews is tried to increase validity and reliability of the research. The data acquired with interviews is compatible with findings of observations. Findings of observation are supporting the data of interviews. In the light of findings above themes, codes and sub-codes are formed and evaluated studiously by each member of profession. Composed themes are consisting "studying and teaching", "socializing and adaptation", "problem behaviors" and "suggestions". Codes and subcodes are formed favorably with these themes.

\section{Findings}

It is concluded that protection of law is abused by the students who are in need of protection. It is defined that students being in need of protection are reluctant to attend studying-teaching activities, having academic failure, are eager to attend social activities but also who are tend to spoil social activity/game. Students being in need of protection require that social acknowledgment of the other students' parents together with teachers and friends. It is determined that students being in need of protection influence each other negatively in both school environment and institution/orphanage environment. It is specified that they are tend to problem behaviors such as aggression against their friends, violating the rules, running away from the school, damaging property of the school. It is determined also existing miscommunication between schools and institutions in which staying students in need of protection.

\section{Result and Discussion}

It is determined that institutional, parental or academically support are not sufficient towards students being in need of protection. Some part of these students are under protection because of family oriented problems, for that reason they are deprived of family support; parental support can affect the academically success of the students. It is defined that students being in need of protection are reluctant to attend studyingteaching activities. It is determined also that they are tend to refuse to attend activities with the opinion of "we are children in need of protection, the law protects us, nothing happens to us". They are eager to attend social activities but also who are tend to spoil social game. It is concluded that children misunderstand the legal protection, for that reason; they are facing with many difficulties both academically and socially. It is confirmed that apartments in which children live contributing social development of children positively. Students being in need of protection are observed being shy in speaking in the classroom. With the reason of protection by law, it is specified that they are tend to problem behaviors such as violating the rules of classroom and school, running away from the school, spoiling the harmony of the course. It is concluded that protection of law is abused by the students who are in need of protection and causes academically insensitivity.

\section{Suggestion}

In order to increase academically success of children being in need of protection they should attend studying and teaching activities, they can also benefit from modern training method and techniques. 
Revision of the legislation oriented to protection of children being in need of protection, making new arrangements considering experience and extensive knowledge of members of profession working in the field of developmental features and psychological situation of the children (teachers and directors, officials and administrators of the institution etc.), and also revision of legislation of educational system, making change in required arrangements might reduce possibility of children pushing to the crime or aimlessness via law.

It may be useful to create environment which provides emotional support for the students being in need of protection, to try to prevent children being in need of protection via family training, public service announcement etc.

In order to prevent students being in need of protection affecting each other negatively both school environment and institution environment it may be useful to obey age group limits in the legislation for institutional care and also where necessary age group can be limited within the bounds of possibility. Interinstitutional communication and common decision making process to eliminate negative behaviors' of children might also beneficial for the children who defined as negative example towards their environment.

As a result, so as to eliminate lack of knowledge of teachers especially legislation and update existing information about juvenile protection, it might be beneficial to organize interagency training seminars, similarly to tend to this field, along with education legislation about courses in faculty of education, putting forward legislation for protection of children might also be useful.

Keywords: Clasroom Training, Primary School, Classroom Instruction Education, Children In Need Of Protection (CNP), Learning and Teaching Process, Encountered Problems, Teachers View, Clasroom Teachers

Öz:) İlkokul kademesinde öğrenim gören ve devlet korumasındaki öğrencilerin öğrenme ve öğretme sürecinde karşılaştıkları sorunların öğretmen görüşlerine göre incelenmesinin amaçlandığ bu çalışma betimsel tarama modeline göre desenlenmiştir. Nitel araştırma yöntemlerinden olan iç içe geçmiş tek durum deseninin çalışmaya uygun olduğu düşülmüştür. Araştırmanın çalışma grubunu, devlet korumasında yer alan öğrencilerin devam ettikleri, farklı üç okulun, farklı sınıflarında görev yapan yapılan 18 öğretmenden oluşmuştur. Çalışma grubu sekiz erkek, on kadın öğretmenden oluşmuştur. Çalışma grubunda yer alan öğretmenlerin görüşleri bu çalışmanın verilerini oluşturmuştur. Yarı yapılandırılmış görüşme formu ile öğretmenlerin görüşleri alınmıştır. Öğretmenlerin görüşlerini desteklemek ya da farkı görmek için farklı günlerde farklı alanlarda, sınıf içinde ve okul bahçesinde olmak üzere 46 saat gözlem yapılmıştır. Gözlem yolu ile veri elde etmek için de öğretmen görüşlerinde olduğu gibi yarı yapılandırılmış gözlem formu kullanılmıştır. Görüşmelerden elde edilen bulgularla gözlem verileri karşılaştırılarak geçerlik ve güvenirlik arttırılmaya çalışılmıştır. Görüşme verileriyle, gözlem bulgularının uyumlu olduğu görülmüştür. Sonuçlar birbirini desteklemiştir. İçerik analizi ile verilerin analizi yapılmıştır. Analiz sonucunda araştırmayla ilgili tema, kod ve alt kodlar oluşturulmuş, her biri alan uzmanları ile birlikte incelenmiş, hassas değerlendirme yapılmıştır. Değerlendirme sonucunda "öğrenme ve öğretme", "sosyalleşme ve uyum”, “problem davranışlar” ve "öneriler" şeklinde temalar oluşmuştur. Bu temalara bağlı kodlar ve alt kodlar oluşturulmuştur. Kanunun koruyuculuğunun devlet korumasındaki öğrenciler tarafindan istismar edildiği belirlenmiştir. Kanunun koruyuculuğundaki öğrencilerin öğrenme öğretme etkinliklerine katılımda isteksiz oldukları belirlenmiştir. Okul başarılarının da düşük olmasına rağmen sosyal etkinliklere katılmaya istekli oldukları belirlenmiştir. Sosyal etkinliğe katılımında oyunun düzenini bozma eğiliminde oldukları tespit edilmiștir. Devlet korumasında yer alan öğrencilerin sosyal kabule ihtiyacı vardır. Diğer öğrenci, öğrenci velisi ve öğretmenin şartsız kabülüne ihtiyaç duyulmaktadır. Hem yuva hem de okulda devlet korumasındaki çocukların birbirlerini olumsuz etkileşimde bulundukları tespit edilmiştir. Kurallara riayet etmeme, okuldan kaçma, okul eşyalarına zarar verme, arkadaşlarına karşı saldırganlık, gibi problem davranış sergilemeye meyilli oldukları belirlenmiştir. Devlet korumasındaki öğrencilere yönelik okullar ile öğrencilerin barındığı kurumlar arasında iletişim yetersizliği tespit edilmiştir.

Anahtar Kelimeler: Sınıf Eğitimi, İlkokul, Korunmaya Muhtaç Çocuk, Öğrenme-Öğretme Süreci, Karşılaşılan Sorunlar, Öğretmen Görüşleri, Sınıf Öğretmeni 


\section{Giriş}

Bir çocuğun korunmaya muhtaç çocuk statüsünde yer alması için koruyucu ve destekleyici tedbir kararı verilebilmesi, birtakım problemlerin hukuken kabul edilmiş oması gerekir. $\mathrm{Bu}$ problemler; ebeveyn yoksunluğu, ihmal, istismar, suça sürüklenmek gibi pek çok sorunlar veya bu nedenlerden kaynaklanan durumlar olabilir.

Devletin korumasındaki çocuklar Türkiye'de, Çalışma, Sosyal Güvenlik Aile ve Sosyal Politikalara bağlı kurumlarda barınmaktadır. Türkiye İstatistik Kurumunun (TÜİK) (2019) verilerine Türkiye yaklaşık 83.000.000 kişiden oluşmaktadır. 2018 y1lı sonu itibariyle devlet korumasında 104729 çocuk yer almaktadır. Aile ve Sosyal Politikalar Bakanlığı verilerine göre (2018) 47344 çocuk hakkında Korunmaya muhtaç çocuk hükmü verilmiştir. Bu sayı Türkiye nüfusunun \%0,06'sına karşı1ık gelirken bir şekilde "Korunmaya Muhtaçlık" kapsamındaki çocuklar (152.073) bireyden oluşmaktadır. Türkiye vatandaşlarının \%0,2'sine tekabül eden bir oranda devlet korumasında yer almaktadır.

Tablo 1: Hakkında Korunma Kararı Verilen Çocuklar (2018 Yı11)

\begin{tabular}{cc} 
Sevgi Evleri gibi devlet korumasındaki bir kurumda barınan & 14.189 \\
Diğer & 33.155 \\
Toplam & 47.344 \\
\hline
\end{tabular}

$\mathrm{Bu}$ çocukların yaşamış olduğu aile ve çeşitli travmalar, yaşamakla beraber çevreye yaşatmış oldukları travmalar nedeniyle kanunlar ve mahmkemelerce haklarında korunma kararı verilmesini ortak özellikleridir. Duygusal taravmalara bağlı sorunlar bireylerin yaşamına ve akademik yaşamına etki edeblmektedir. Razon (2007) çalışmasında duygusal sorunların çocuğun okul başarısını etkilediği sonucuna ulaşmıştır. Yine Başar ve Batur (2018) çalışmasında duygusal sorunu olan öğrencilerin okuma hatalarının arttığını ve okuduğunu anlama başarısının düştüğünü tespit etmiştir. Çocuğun öğrenme öğretme sürecindeki sorunlarının sadece akademik başarıdan ibaret olmayacağının sorunun çocuğun güncel yaşamını da etkileyebilceği de gözöüne alınmalıdır. Devlet korumasında yer alan çocukların öğrenme öğretme sürecinde yaşadıkları sorunlar ortaya konulamadığı zaman bu çocukların sorunları çözüme ulaşamadan kendi içinde kartopu gibi büyüyerek çoğalacaktır. Korunmaya muhtaç çocuk kapsamındaki öğrencilerin, özellikle öğrenmeöğretme sürecinde yaşadıkları ve çevresine verdikleri sorunların ortaya konulması sorunların çözümü için temel oluşturabilecektir. Bu nedenele böyle bir çalışma yapılma ihtiyacı doğmuştur. Konunun eğitim bilimlri açısından çok az çalışmaya rastlanılmış olması, korunmaya muhtaç çocukların öğrenme-öğretme sürecinde karşılaştıkları sorunların ele alındığı bir çalışmaya ise rastlanılamamış olması çalışmanın bu alanda boşluğu dolduracağı düşünülmüştür.

\section{Araştırmanın Amacı}

Korunmaya muhtaç çocuk kapsamında devlet korumasında yer alan öğrencilerin, öğrenmeöğretme sürecindeki sorunlarının öğretmen görüşlerine göre incelenmesinin amaçlandığı bu çalışmada aşağıdaki sorulara cevap aranmıştır.

1) Korunmaya muhtaç çocuk kapsamındaki öğrencilerin öğrenme-öğretme süreci ile ilgili karşıllaştığı sorunlar nedir?

2) Korunmaya muhtaç çocuk kapsamındaki öğrenciler, uyum ve sosyalleşme problemlerini nasıl yaşamaktadır?

3) Korunmaya muhtaç çocuk kapsamındaki öğrencilerde görülen problem davranışlar nelerdir? 


\section{Yöntem}

\section{Araştırmanın Modeli}

$\mathrm{Bu}$ çalışma, betimsel tarama modeline göre tasarlanan bu çalışmada nitel araştırma yöntemlerinden iç içe geçmiş tek durum deseninin çalışmaya uygun olacağı düşünülmüştür. Yıldırım ve Şimşek'e göre (2016) “Tek bir durum içinde çoğu kez birden fazla alt tabaka veya birim olabilir. $\mathrm{Bu}$ durumda birden fazla analiz birimi söz konusu olacaktır. Buradaki ayrım, bir durum çalışmasının ilgili durumu, bütüncül ve tek bir ünite olarak ele almasına veya bir durum içinde olabilecek birden fazla alt birime yönelmesine ilișkindir.” $\mathrm{Bu}$ araștırmanın tek durumu öğrencilerin, korunmaya muhtaç çocuk olmalarıdır. Bu araştırmanın birden çok alt anakiz birimi vardır. Bu alt analiz birimleri sosyalleşme ve uyum, öğrenme-öğretme, problem davranışlar ve öğretmen önerilerinden oluşmuştur.

\section{Çalışma Grubu}

Araştırmanın çalışma grubunu, korunmaya muhtaç çocuk kapsamındaki öğrencilerin öğrenim gördükleri, üç farklı okulda görevli 18 öğretmenden oluşmuştur.

Bu araştırmanın çalışma grubu amaçlı örnekleme göre belirlenmiştir. Öğretmenlerin devlet korumasında bulunan korunmaya muhtaç öğrencilerin öğrenim gördüğü sınıflarda görevli olmaları nedeniyle amaçlı örneklem yöntemlerinden benzeşik homojen grubu oluşturmuştur. Yıldırım ve Şimşek'e göre (2016) homejen grup oluşturulmasının nedeni küçük, benzeşik bir örneklem oluşturma yoluyla belirgin bir alt grubu tanımlamaktır. Çalıșma grubunda yer alan öğretmenlerin

korunmaya muhtaç öğrencilerin bulunduğu sinıfta görev yapması benzeşik homojen grubu oluşturmaktadır. Öğretmenlerin çalışma grubuna karılımı gönüllü olma durumuna göre belirlenmiştir.

\section{Veri Toplama Aracı}

$\mathrm{Bu}$ araştırmada veri toplama aracı olarak yarı yapılandırılmış görüşme ve gözlem formu kullanılmıştır. Büyüköztürk vd (2011) gözlemi, araştırmada ihtiyaç duyulan verilerin insan, toplum ya da doğa gibi belli hedeflere odaklanılarak çıplak gözle ya da bir araç kullanılarak izlenmesi suretiyle toplanması süreci olarak tanımlamıştır. Araştırmanın veri toplama aracı yarı yapılandırılmış görüşme formunun oluşturulması için ilk önce ilgili literatür taranmıştır. Literatür taramasından sonra, görev yaptı̆̆ 1 sınıfta Korunmaya muhtaç çocuk kapsamındaki öğrencisi olan farklı sınıflarda görevli 5 öğretmene, korunmaya muhtaç öğrenci kapsamında yer alan çocukların öğrenme ve öğretme sürecinde yaşadıkları problemler sorulmuştur. Öğretmenlerden veplarını kompozisyon şeklinde yazmaları istenmiştir. Öğretmenlerden elde edilen verilere içerik analizi yapılmıştır. Üç alan uzmanı tarafından incelenen bu verilerden, uzmanların görüş birliğine vardığı veriler, araştırmanın yarı yapılandırılmış görüşme formunda soru olarak yer almıştır. Uzmanların uyuşum oranı \%92 olarak belirlenmiştir.

Araştırmada sınıf içi gözlemler yarı yapılandırılmış bir gözlem formu ile toplam 46 saat gözlem yapılmıştır. Gözlemin 36 altı saati altı farklı sınıfta, 10 saati okul bahçesinde yapılmıştır. Yarı yapılandırılmış gözlem formu, görüşme yolu ile elde edilen verilerden elde edilen tema, kod, alt kodlara göre hazırlanmıştır. Gözlem formu uzman görüşüne sunulmuş, görüş birliği sağlanan maddeler gözlem formuna alınmıştır.

\section{Verilerin Analizi}

Görüşülen öğretmenlere, kendilerinden hiçbir yerde hiçbir ortamda bahsedilmeyeceği verilerin (Ö1, Ö2, gibi) her bir öğretmen için ayrı bir kodlanacağ 1 belirtilmiştir. Görüşmelerde, katılımcılar için süre ile ilgili bir sınırlama yapılmamıştır. Süreye yönelik herhangi bir sınırlama olmadığından öğetmenler görüşlerini rahat ve özgürce ifade edebilmiştir. Öğretmenlerin görüşleri süreye bağlı olarak alınmamıştır. Bu durumda da araştırmanın verileriyle ilgili düşüncelerini baskı altında kalmadan söyleyebileceği düşünülmüştür. Araştırmanın verileri kapsamında katılımcılarla 
okul idaresinin uygun gördüğü dışarıdan dikkat çekmeyen bir ortamda görüşülmüştür. Öğretmenlerin görüşleri araştırmacılar tarafından yazılarak kayıt altına alınmıştır. Tutulan kayıtlar öğretmenlere yeniden okunarak eklemek ya da çıkarmak istedikleri bölümler olup olmadığı sorulmuştur. Öğretmenlerin belirttiği ekleme ve çıkarmalar da yapılmıştır.

Araştırmanın verilerinin kodlanmasından sonra veriler içerik analizi ile analiz edilmiştir. $\mathrm{Bu}$ aşamada öğretmenlerin görüşlerinden elde edilen verilerden benzer ifade içerenler veya anlamları aynı olanlar gruplanarak temalara ulaşılmıştır. Temaların, kod ve alt kodların matriksini oluşturma süresinde, güvenirliğin ve geçerlik sağlanması için alan uzmanlarından desteğine başvurulmuştur. Tema, kod ve alt kodlar sürecin sonunda, uzmanların, aralarında uyum sağlamalarına göre alınmıştır. Belirlenen alt kodların görülme sıklığı tespit edilmiştir. Araştırmanın çalışma grubunu oluşturan öğretmenlerin ifadeleri, doğrudan alıntı şeklinde yer almış ve ulaşılan sonuçlar bu ifadelerden yola çıkılarak açıklanmıştır. Ögrretmenlerle yapılan görüşmelerden, sınıf içi ve okul bahçesi gözlemlerinden elde edilen veriler için uzman görüşü alınmıştır. Uzmanların üzerinde $\% 85$ ve üzeri uyuşum sağladığı veriler tema, kod, alt kod olarak araştırmanın bulguları olarak sunulmuştur. Araştırmanın görüşme verileriyle gözlem verilerinin genelde uyumlu olduğu sonucuna varılmıştır. Uzmanların uyuşum oranının \%90 olduğu belirlenmiştir.

\section{Bulgular}

Tablo 2: Öğrenme Öğretme İle İlgili Sorunlar

\begin{tabular}{|c|c|c|c|}
\hline Tema & Kod & Alt Kod & $\mathbf{f}$ \\
\hline \multirow{21}{*}{ 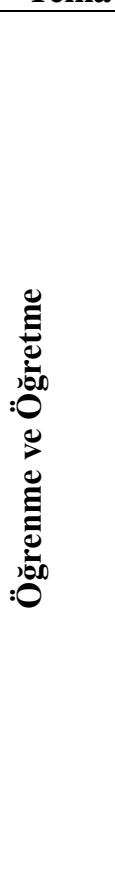 } & & Akademik destek & 7 \\
\hline & Okul Dışı & Duygusal destek & 5 \\
\hline & Destek & Hukuki destek & 4 \\
\hline & & Ailesel destek & 4 \\
\hline & & Kabullenici yaklaşım & 5 \\
\hline & & Sosyal Kabul & 1 \\
\hline & Öğretmen & Rehberlik edici/Yönlendirici yaklaşım & 5 \\
\hline & Tutumu & Bütünleş̧tirici yaklaşım & 8 \\
\hline & & Yüceltme & 2 \\
\hline & & Empatik yaklaşım & 1 \\
\hline & & Yasal Koruma & 4 \\
\hline & & Sorumluluk-hak çatışmast & 1 \\
\hline & & Aidiyet duygusu & 2 \\
\hline & Sınıf Yönetimi & Uyumluluk & $\mathbf{1}$ \\
\hline & & Pekiştireç kullanma & 2 \\
\hline & & Odaklanma & 1 \\
\hline & & Psikolojik Ihtiyaç & 4 \\
\hline & Akademik & Ortam etkileşimi & 5 \\
\hline & Başarı & Öğrenmeye isteklilik & 8 \\
\hline & & Geçmiş yaşantılar & 5 \\
\hline & Motivasyon & Pekistireç kullanma & 1 \\
\hline
\end{tabular}

Tablo 2'de, öğretmenlerin, öğrenme ve öğretme temasıyla ilgili görüşlerinden elde edilen verilere yer verilmiştir. Okul dışı destek kodu öğrenme öğretme temasına bağlı olarak oluşan kodlardan birisidir. Bu kod kapsamında akademik destek, duygusal destek, hukuki destek kültürel destek ve ailesel destek alt kodları oluşmuştur.

Akademik destek alt kodunda Korunmaya muhtaç çocuk kapsamında yer alan öğrencilere kurumsal ve ailesel akademik destek yeterince sağlanamamaktadır. Bu öğrencilerin akademik desteğe ihtiyaçlarının olduğu belirtilmiştir. Bu konuda Ö16 "Bu öğrencilerin ödev vb. okul dış1 kapsamı eksik kalıyor" diyerek okul dışı akademik desteğin eksikliğine vurgu yapmıştır. Ö5 "Ders 
çalıştırmak için kurum içinde ilgilenen kişiler az ilgileniyor gibi.” Öğretmen, kurum desteğinin yetersiz kalmasının öğrencinin akademik yetersizliğine neden olduğunu ortaya koymuştur.

Duygusal destek alt kodunda, korunmaya muhtaç çocuk kapsamındaki öğrencilerin duygusal desteklerinin yetersiz ya da hiç olmaması nedeniyle karşılaşılan sorunlara değinmiştir. Ö7 "Bu çocukların başarılarının artmasının moral ve motivasyonunun artmasına bağlıdır. Moral ve motivasyon başarıryı olumlu etkileyecektir" diyerek duygusal desteğe vurgu yapmıştır. Ö8 "Korunmaya muhtaç çocukların en önemli ihtiyaçlarından birisinin de doyurulamayan sevgi ihtiyacı olduğu söylenebilir. Şartsız kabul ve sevgi başarıyı getiriyor. Bu kurumlar birçok başarılı insan yetiştirmiştir." Şartsız kabulün ve sevgi desteğinin bu öğrencilerin akademik başarı için önemini ortaya konulmuştur.

Hukuki destek alt kodunda Korunmaya muhtaç çocuk kapsamında bulunan öğrenciler yasaların sağladığı korumacılığın farkına varmıştır. Yaş olarak büyük öğrenciler bu korumayı hem davranışlarıyla hem de sözel olarak alt yaş grubundaki öğrencilere hissettirmektedir. Bu hissetmeyele birlikte korunmaya muhtaç çocukların okula ilgisinin ve başarısının azalmasına neden olabildiği belirtilmştir. Sınıf içi gözlemlerde de korunmaya muhtaç çocuk kapsamındaki öğrencilerin sınıfta derslere katılmayarak ilgisiz oldukları gözlemlenmiştir. Kanunun koruyuculuğunun çocuklar tarafından istismar edildiği öğretmen ifadelerinde görülmüştür. Bu konuda Ö9 "Bu çocuklarda "biz yuva-yurt çocuğuyuz, bize bir şey olmaz, öğretmen bize bir şey yapamaz" düşüncesi var.” diyerek, kanunun sağladığ 1 bu sorunu ifade etmiştir. Mevzuattan kaynaklanan sorunu Ö11 "İlkokulda öğrenclere yönelik resmi disiplin kuralları bulunmamaktadır. Bu soruna bağlı olarak, kanun ile de korunuyor olmaları da bir başka sorun.” şeklinde belirtmiştir. Öğretmen hukuki korumanın uygulamada karşılaşılan yanlışlara değinmiştir. Hukuki desteği yanlış algılayan öğrenciler, okulu önemsemeyerek okuldan izinsiz ayrılma, öğrenme öğretme sürecine katılmayarak öğrenmeye direnme gibi istenmeyen öğrenci davranışları sergileyebilmektedir. Sınıf içi gözlemlerde de korunmaya muhtaç çocuk kapsamındaki öğrencilerin, öğretmendenizin almaksızın sınıftan çıkabildikleri buna karşın sınıftaki diğer öğrencilerde böyle bir davranış gözlemlenmemiştir. Araştırmanın gözlemleri ile öğretmenlerin düşünceleri birbirine paralellik göstermektedir.

Ailesel destek alt kodunda korunmaya muhtaç çocuk kapsamındaki öğrencilerin aile bölünmüşlüğü, anneden veya babadan birisini ya da her ikisini kaybetme nedeniyle korunmaya muhtaç çocuk kapsamına alınmıştır. Bu nedenlerle öğrencilere aile desteği akademik anlamda sağlanamamaktadır. Bu konuda Ö2 "Veliler, okulu ve öğretmeni ziyaret etmiyorlar, aile ilgisizliği çocuğu akademik olarak yetersiz k1lıyor." Öğretmen, veli ilgisizliğinin ortaya koyduğu sorunu belirtmiştir. Hangi konumda bulunursa bulunsun korunmaya muhtaç çocuk bile olsa aile desteğinin öğrencilerin akademik başarısını etkilediği belirlenmiştir.

Öğretmen tutumu koduna bağlı olarak kabullenici yaklaşım, yönlendirici/rehberlik edici yaklaşım, bütünleştirici yaklaşım, yüceltme ve empatik yaklaşım alt kodları oluşmuştur.

Kabullenici yaklaşım alt kodunda, Korunmaya muhtaç çocuk kapsamındaki öğrencilerin, öğretmenler tarafindan şartsız kabul gördüklerinde öğrencilerin bu şartsız kabule olumlu tepki verdikleri dile getirilmiştir. Bu konuda Ö5 "sınıfımdaki öğrenciler korunmaya muhtaç çocuk kapsamındaki öğrencilerimi seviyorlar. Korunmaya muhtaç çocuk kapsamındaki çocuklara yardım etmeye çalışıyorlar. Öğretmenin bu çocuklara sahip çıkma düzeyi sınıfın da sahip çıkma düzeyi aynı orantıda oluyor." Öğretmen, bir öğrencinin korunmaya muhtaç çocuk kapsamındaki bir öğrenciyi bir öğretmenin şartsız kabul etmesinin sınıf arkadaşları tarafından kabul edilmelerindeki önemi ortaya koymuștur. Gerek sınıflarda gerekse okul bahçesindeki gözlemlerde öğretmenlerin korunmaya muhtaç çocuk kapsamındaki öğrencilerini şartsız kabul ettikleri, ilgi çekmek, derse katmak, takdir etmek gibi öğretmen davranışları söz konusu olduğunda diğer çocuklara olduğu derecede ve eşit davrandıkları, Korunmaya muhtaç çocuk kapsamındaki öğrencilerin sınıf arkadaşları tarafından öğrenme öğretme sürecinde yalıtılmadıkları görülmüştür. 
Sosyal kabul alt kodunda öğretmen; korunmaya muhtaç çocuk kapsamındaki öğrencilerin, sınıf içerisinde kabul görmemeleri halinde akademik anlamda başarısız olabildiklerine değinmiştir. Ö8 "Sınıftaki arkadaşları dışlarlarsa korunmaya muhtaç kapsamındaki çocuklar akademik olarak yetersiz kalıyorlar” diyerek, sınıf arkadaşlarının sosyal kabulünün önemine vurgu yapmıştır.

Rehberlik edici/yönlendirici yaklaşım alt kodunda, korunmaya muhtaç çocuk kapsamındaki öğrencilerin, öğrenme öğretme sürecinde rehberliğe ve yönlendirmeye ihtiyaç duydukları belirlenmiştir. Ö5 "Korunmaya muhtaç çocuk kapsamında olan bir öğrencimin dikkati çok çabuk dağılıyordu. Görsel alanda takibi daha iyi, dikkati daha yoğundu. Şarkıları kolay ezberliyordu. Resim yaptırarak derse ilgisini arttırmaya çalıştım.” diyerek öğrencisinin derse olan ilgisini, derse katılımını ve ders başarısını arttırmak için öğrencisini resim alanına yönlendirdiğini belirtmiştir. Sınıf içinde yapılan gözlemlerde de; öğretmenlerin sınıf içerisindeki öğrencilerin tümüne eşit söz hakkı vermeye özen gösterdikleri, korunmaya muhtaç çocuk kapsamındaki öğrencilere de söz hakk1 vermeye çalıştıkları, öğrencilerin dikkatini ve ilgisini derse çekebilmek için çeşitli tekniklerden yararlandıkları görülmüştür.

Bütünleştirici yaklaşım alt koduna bağlı olarak öğretmenler; korunmaya muhtaç çocuk kapsamındaki çocukların, bütünleştirici yaklaşımın özellikle uyum problemlerinin ve sınıf arkadaşları ve eğitimin paydaşları tarafından kabul görme sorunlarının aşılmasında bütünleştirici yaklaşımın faydalı olduğunu belirtmiştir. Ö12 "Okulun öğrencisi ve çevre korunmaya muhtaç çocukları kabullenmekte zorluk çekiyorlar. Korunmaya muhtaç çocukların sınıf arkadaşları tarafından kabul görülmesi için çaba harciyorum" diyerek öğretmenin bütünleştirici tutumunu vurgulamıştır. Korunmaya muhtaç öğrencilerin ayrıştırılmak yerine toplumun bir parçası, sınıf arkadaşlarından bir farklılığının olmadığı hissettirildiğinde bütünleştirmeye yönelik dönütler alınabildiğini ortaya koymuştur. Gözlem yapılan sınıflarda, öğretmenlerin ve sınıf arkadaşlarının bütünleştirici yaklaşım içinde oldukları, korunmaya muhtaç öğrencileri dışlamadıkları, onları sınıfın bir parçası olarak gördükleri, onları farklılaştırmadıkları gözlemlenmiştir. Bütünleştirici yaklaşım ile ilgili öğretmenler tarafından belirtilen durumlar ile gözlem sonuçlarının birbirini destekledikleri görülmüştür.

Yüceltme alt kodunda öğretmenler; korunmaya muhtaç çocuk kapsamındaki öğrencilerin, doğru davranışlarının takdir edilerek yüceltilmesinin önemine değinmiştir. Bu kapsamda Ö9 "Korunmaya muhtaç çocukların davranış ve tutumlarındaki iyi örnekleri sınıftaki arkadaşlarıyla da paylaşıyorum" diyerek yüceltmeye vurgu yapmıştır. Aynı konuda Ö12 korunmaya muhtaç çocukların gerek sınıf içerisinde gerekse okulda gösterdikleri olumlu tutum ve davranışlarıyla, farklı başarılarıyla daha fazla kendilerini gösterebilmelerinin kabul ve uyum sorunları azaltacağını belirtmiştir. Korunmaya muhtaç çocukların öğrenme öğretme süreciyle birlikte toplumsal düzeyde, kabul görmesinin sağlanabileceğini ve uyum sorunlarının azaltılabileceği vurgulanmıştır. Yapılan gözlemlerde; bir öğretmen; nöbeti sırasında, yere düşmüş bir karton kutuyu alıp çöp kutusuna atan korunmaya muhtaç çocuk kapsamındaki öğrencisinin davranışını, sınıfta örnek göstermiş, öğrenciye de teşekkür etmiştir.

Empatik yaklaşım alt kodunda öğretmen; korunmaya muhtaç çocuk statüsündeki öğrencilerin, sorunlarının kaynağı geçmiş yaşantılarının onları etkileyen durumları bilmenin, bu çocuklara yönelik empati geliştirmenin onları anlamadaki faydasına değinmiştir. Ö12 "Kendi çocuğumda özel gereksinim gerektiren çocuğuma otizm spektrum bozukluğu tanısı konulması böyle öğrencilere yönelik empati kurmamı, empatik yaklaşım sergilememi sağladı. Bu çocukların öyküsünü bilmek, öğretmenin bu çocuklara yaklaşımını etkiliyor" diyerek çocukların geçmişini tanımanın, empatik davranmayı kolaylaştırdığını belirtmiştir.

Öğrenme ve öğretme temasına bağlı olarak oluşan kodlardan biri de sınıf yönetimi kodudur. Sınıf yönetimi koduna bağlı olarak Sosyal kabul, sorumluluk-hak çatışması, yasal koruma, uyumluluk, aidiyet duygusu, odaklanma ve pekiştireç kullanma alt kodları ortaya çıkmıştır. 
Gözlemlerde, birinci ve ikinci sinıflarda sosyal kabule yönelik bir sorun görülmezken ilerleyen sınıf düzeyinde bu olasılığın çoğaldığı gözlemlenmiştir. Örneğin ikinci sınıfta öğrenim gören öğrenci bir önceki derste fiziksel şiddet düzeyinde tartıştığı arkadaşıyla bir sonraki dersin teneffüsünde birlikte oyun oynarken görülmüsstür. Alt sinıflarda sosyal kabul sorunun pek yaşanmadığ 1 gözlenmiştir.

Yasal koruma alt koduna bağlı olarak öğretmenler; korunmaya muhtaç çocuk statüsündeki çcukların, kanuni düzenlemelerin kendilerine verdiği haklar ya da mevzuatın yetersizliği bulunmaktadır. $\mathrm{Bu}$ çocuklar hiçbir şekilde, yaptıklarından dolayı sorumluluk taşımayacakları, kendilerine yasal veya gayri resmi bir ceza verilemeyeceği gibi algılamalarından dolayı ortaya çıkan sorunları dile getirmiştir. Ö9 "Korunmaya muhtaç çocuklarda "biz yasa ile korunan çocuklar olmamaız nedeniyle öğretmen ya da başkası bize dokunamaz" fikri etkili" olduğunu belirterek korunmaya muhtaç öğrencilerin, yasanın kendilerine sağladığ 1 korumacıllğa yönelik bakış açısını ortaya koymuştur. Bu düşüncenin, korunmaya muhtaç çocuk kapsamındaki öğrenciler arasında akran iletişimi ile sağlanabildiği belirtilmiştir. Ö1 "Korunmaya muhtaç çocuklar barındıkları kurumlarda birbiri ile etkileşiyor. Öğretmen sizi dersle ödevlendiremez. Bizlere bir şey yapılamaz. Dersi, okulu takmayın isteyince okulu kırabilirsiniz.” diyerek durumu özetlemiştir. Mevzuat noktasında eksiklik bulunması, kanunun yalnızca "koruma" üzerine düzenlenmiş olması, mevzuatta yaptırım bulunmaması veya mevcut yaptırımların yetersiz olması durumunu Ö13 "Bu çocuklarda dokunulmazlıkla sağlanmış güvence var. Yasanın sağladığ 1 bu güvence birçok soruna neden olabilmekte. İstenmeyen davranışlarının bir yaptırımı olmalı" demiştr. Ö11 "İlkokulda bir yaptırım bulunmaması sorunu var. Korunmaya muhtaç çocukların kanun ile de korunmaları da başka bir sorun" diyerek yasal korumdan kaynaklı sıkıntıları dile getirmiştir. Korunmaya muhtaç çocuk kapsamındaki öğrencilerin sınıf düzenini, ders akışını bozacak davranış ürettikleri, kendilerine öğretmenleri tarafından sorulan son derece kolay sorulara dahi yanıt vermeyebildikleri, sınıftan izinsiz olarak çıktıkları gözlemlenmiştir.

Sorumluluk-hak çatışması alt kodunda öğretmenler; korunmaya muhtaç çocuk kapsamındaki öğrencilerin, yasal düzenlemeleri yanlış algılamalarından dolayı kendilerinin ve çevrelerinin yaşadığı problemlere değinmiştir. Ö9 "Çocuklar, kanunun kendilerine tanımış olduğu kazanımlarla ilgili yanlış algıları var. Sınıf düzenini bozmak, dersten veya okuldan kaçmak, öğretmene karşı gelmek gibi davranışları kanunun koruyuculuğu sayesinde rahatça yapabileceklerini düşünüyorlar. Haklarını korumak, yasa güvencesi altında bulunuyor olmak adına yanlış yapıyorlar. Yasayla düzenlenmiş haklarının bulunmasının, yerine getirmesi gereken sorumlulukları ortadan kaldırdığını zannediyorlar" diyerek, yasal korumayla sağlanan güvencenin kendilerini dokunulmazlık zırhına büründürdüğü fikrinin neden olduğu problemleri söylemiştir.

Aidiyet duygusu alt kodunda öğretmenler; korunmaya muhtaç çocuk kapsamındaki öğrencilerin, kendilerini bazı zamanlarda toplumun bir ferdi olarak düşünememelerinin çocuğu olumsuz etkileyebildiğini ortaya koymuştur. Ö2 "Bu öğrenciler kendilerini bu sınıfin bir parças1 olarak göremeyebiliyorlar. Bu durumun nedeni de geçmiş yaşantı ve okul dışı hayatlarıdır. Bunlar çocuğun olumsuz tutum ve davranışlarının nedenlerini oluşturuyor." Öğretmen, çocuğun geçmiş yaşantılarının eğitim-öğretim yaşantılarına olumsuz yansımasını belirtmiştir. Yapılan gözlemlerde, korunmaya muhtaç çocuk kapsamındaki öğrencilerin genel olarak öğrenim gördüğü sınıfin bir parçası olmak yerine hiçbir yere aidiyeti olmayan rastgele hareket eder gibi davrandıkları izlenimi edinilmiştir. Gözlem sonuçları ile öğretmen görüşlerinin birbirini destekledikleri söylenebilir.

Uyumluluk alt kodunda öğretmen; korunmaya muhtaç çocuk kapsamındaki öğrencilerin, sınıf yönetiminine göre değerlendirildiğinde uyum sorunu yaşamadıklarına değinmiştir. Korunmaya muhtaç çocuk kapsamında olmasına rağmen, sınıf içerisinde uyum problemi yaşamayan, öğrenme öğretme sürecine etkin katılım sağlayan, sınıf düzeni gibi konularda herhangi bir problem davranışı gözlenmeyen öğrencilerin de bulunduğunu Ö16 "Sınıf içinde sınıf düzenini bozmaya yönelik 
korunmaya muhtaç çocuklardan dolayı istenmeyen öğrenci davranışı görülmüyor.” şeklinde ifade etmiştir. Sınıf yönetimi açısından, istenmeyen öğrenci davranışı göstermeyen, sınıf düzenini bozma eğiliminde olmayan korunmaya muhtaç çocuk kapsamında öğrencinin bulunması Ö16 tarafindan dile getirilmiştir. Bu durum korunmaya muhtaç öğrencilerin de geçmiş yaşantılarına rağmen olumsuz durumlardan etkilenmeyebileceğini göstermiştir.

Pekiştireç kullanma alt kodunda öğretmenler; korunmaya muhtaç çocuk kapsamındaki öğrencilerin, olumlu davranışlarının kalıcılığını sağlamak için veya sınıf içinde bu öğrencilerin istenmeyen öğrenci davranışlarına yönelmelerini engellemek hedefiyle pekiştireç kullandıklarını ifade etmişlerdir. Ö9 "Öğrencimi ödüllendirme yaparak yönlendirebiliyorum, öğrenme öğretme sürecine katılımını ancak böyle sağlayabiliyorum. Pekiş̧ireç kullaılmadan öğrencinin sınıf içerisinde yönledirilmesi güçleşiyor. Ödül olarak şeker çikolata gibi yiyecek içecek verme, motive edici söylemler, yardımcı olarak ban yardım etmesine izin verme türü pekiştireçler kullanıyorum" demiştir. Ö1 "Örneğin övgü sözleri gibi ikincil tür pekiştireçlerle, kontrol altına alıyorum." Öğretmen pekiştirecin korunmaya muhtaç çocukların yönlendirilmesinde etkisine vurgu yapmıştır.

Odaklanma alt kodunda öğretmenler; korunmaya muhtaç çocuk kapsamındaki öğrencilerin, sınıf istenmeyen öğrenci davranışları açısından yönlendirebilme çalışmalarını belirtmiştir. Ö1 "Korunmaya muhtaç çocuk kapsamındaki öğrencilerimin sınıf içerisindeki oturma düzenini değiştirterek farklı yerlerde oturtuyorum" şeklinde ifadesiyle sınıf içi istenmeyen öğrenci davranışlarının yönetiminde oyurma düzenine yönelik stratejisinden nasıl yararlandığını belirtmiştir.

Derse giriş aşamasında, öğretmenlerin, dikkat çekme/güdüleme basamağına önem verildiği görülmüş̧ür. Öğretmenler tarafından derse giriş başmağının gereği etkinliklere dikkat çekme ilgi oluşturmaya yönelik yer verilmesine rağmen, korunmaya muhtaç çocuk kapsamındaki öğrencilerin derse ilgi göstermedikleri gözlemlenmiştir. Kolay anlaş1lır direktifleri yerine getirmede zorlandıkları, öğrenme öğretmeye yönelik bir etkinliğe (yazı yazma, resim çizme, sınıf içi oyunlar vb.) sınırlı sürede (4-5 saniye gibi) katıldıkları, ilgi ve yönelimlerinin değiştiği, ders dışı mateyallerle ilgilendikleri, dersi manipüle edebilecek davranışlar görülmüştür. Dersin konusuyla ilgili bir çizgi film gösterildiğinde dikkat süresi artmasına rağmen (20-25 saniyeye kadar) sinıftaki diğer öğrencilerin dikkat süresi kadar takip etmedikleri görülmüştür. $\mathrm{Bu}$ öğrenciler, derse odaklanamadıkları gibi, ayrıca ders akışını olumsuz etkileyebilenistenmeyen öğrenci davranışları da göstermiştir. Bir öğretmen, korunmaya muhtaç çocuk kapsamındaki bir öğrenciyi hem dikkatini derse vermesini sağlamak hem de arkasında oturan arkadaşının eşyalarını kurcalamak suretiyle arkadaşını rahatsız etmesini engellemek amacıyla, öğrencinin oturma yerini değiştirerek öğretmen masasına oturttuğu gözlemlenmiştir.

Öğrenme ve öğretme temasına bağlı olarak oluşan kodlardan biri de akademik başarı kodudur. Akademik başarı koduna bağlı olarak öğrenmeye isteklilik, öğrenme yalıtımı, geçmiş yaşantılar, psikolojik ihtiyaç, ortam etkileşimi alt kodları oluşmuştur.

Psikolojik ihtiyaç alt kodunda öğretmenler; korunmaya muhtaç çocuk kapsamındaki öğrencilerin, psikolojik ihtiyaçlarına değinmişlerdir. Öğretmenler, bu ihtiyaçları; mutluluk, sevgi, ilgi, güven ihtiyacı olarak ifade etmişlerdir. Ayrıca, öğrenme güçlüğü gibi bir problem durumdan da söz edilmiştir. Sevgi ihtiyacını Ö12 "Bu çocuklar sevgiye muhtaçlar.", Ö15 "Bu çocukların sevgiye ihtiyaçları var. Bu çocukların mutluluğa ihtiyaçları var." şeklinde dile getirmiştir. Psikolojik ihtiyaçlarının karşılanmasının gerektiği, bu ihtiyaçlarının karşılanması durumunda öğrenci başarısının artabileceği vurgulanmıştır. Bu konuda Ö11 "Bu çocukların duygusal boşluğunun doldurulması gerekir. Sarsıntılarına uygun (psikolojik, sosyal vb.) müdahale gerekir.", Ö15 "Bu çocuklara gösterilecek sevgi, güveni getirecektir. Bu da başarıyı getirecektir." demiştir. Bu ihtiyaçlarının karşılanmasının, öğrenciler üzerinde olumlu etkilerinin olabildiği, öğretmen ifadelerinden anlaşılmaktadır. Ö11 "Bu çocuklar sevildiğinde, bu çocuklar ile ilgilenildiğinde 
akademik anlamda, sosyal anlamda filan iyiye gidiyorlar.” diyerek, öğrenciler üzerindeki olumlu etkilere vurgu yapmıştır.

Ortam etkileşimi alt kodunda yuva/yurt ortamından ev uygulamasına geçmiş olmalarının çocuklara olumlu yansıdığı öğretmenlerin ortak görüşü olarak ortaya çıkmıştır. Ev uygulamasından yuva/yurt uygulamasına geri dönüş olduğunda ise çocukların olumsuz etkilendiği, oluşan olumlu havanın kaybolmaya başladığı ifade edilmiştir. Bu konuda Ö14 "Yuva ve yurt ortamında değil de ev ortamında olduklarında eğitim-öğretim süreçleri ve sosyal ilişkiler açısından daha iyi oluyorlar. Yuva-yurt ortamına geri döndüklerinde bu durum tersine dönüyor ve seviyeleri düşüyor." diyerek bu duruma işaret etmiştir

Öğrenmeye isteklilik alt kodunda öğretmenler; korunmaya muhtaç çocuk kapsamındaki öğrencilerin, akademik başarılarının düşmesini etkili etkilediğini düşündükleri öğrenmeye isteklilik konusundaki görüşlerini ortaya koymuştur. Korunmaya muhtaç çocuk kapsamındaki öğrencilerin ders içinde teşvik edildiklerinde öğrenme isteğinin arttı̆̆ına vurgu yapmıştır. Bu öğrencilerin öğrenmeye ilgi ve isteğinin genel itibariyle düşük olduğu öğretmenler tarafindan dile getirilmiştir. Ö16 "Bu çocukların öğrenme öğretme sürecine katılım arzusu yetersiz", Ö5 "Dersle ilgileri pek olmuyor.”, Ö12 "Bu çocuklar derse ilgisiz olabiliyorlar.” Ö17 "Bu öğrencilerin akademik seviyeleri düşük. Zaten genelde derse ve okula gelme konusunda, okumak/eğitim almak konusunda isteksizler." diyerek, bu öğrencilerin öğrenme isteğinin az olabildiğini ifade etmişlerdir. Ö9 "Bu güne kadar korunmaya muhtaç çocuk kapsamında yalnızca bir öğrenciye rastladım. Bu isteklilikte ağabeyinin etkisi oldu. Ağabeyi okuması kardeşini destekdi.” demiştir. Çocuğun, bu yönde bir teşvik ve destek alması durumunda öğrenmeye karşı istekliliğinin artabileceği belirtilmiştir. Sınıfta yapılan gözlemlerde; Korunmaya muhtaç çocuk kapsamındaki öğrencilerin öğrenme ve öğretme etkinliklerine katılımın, ortalamasının sınıftaki arkadaşlarına oranla çok düşük olduğu görülmüştür. Korunmaya muhtaç çocuk kapsamındaki öğrencilerin, öğretmenin söz hakkı vermesine, etkinliklere katılımının istenmesine rağmen bu konuda istekli davranmadıkları görülmüştür. Öğretmen, korunmaya muhtaç çocuk kapsamındaki bir öğrenciye, sorulan soruyu cevaplamasını istemişti. Korunmaya muhtaç çocuk kapsamındaki öğrenci yerinden kalkmasına rağmen soruyu cevaplamayı reddetmiş, omuzlarını silkeleyerek tekrar yerine oturmuştur.

Geçmiş yaşantılar alt kodunda öğretmenler; korunmaya muhtaç çocuk kapsamındaki öğrencilerin, geçmiş yaşantılarının bu öğrencilere etkisine değinmiştir. Öğretmen görüşlerine göre bu etkiler, öğrenciye olumsuz yansımaktadır. 5395 sayılı kanun, koruma altına alınacak çocuğun çeşitli dezavantajlı grup içinde yer alması şartı koymuştur. Ö2 "Bu öğrencilerin geçmişteki yaşantılarındaki sorunlar, okul dönemine ve sonraki hayatlarına yansıyor." Ö13 "Çocuğun geçmiş yaşantıları, çocuğu etkiliyor" diyerek geçmiş yaşantıların korunmaya muhtaç kapsamındaki çocuklar üzerindeki etkisini ortaya koymuştur. Akademik yaşamını da engellediğine yönelik Ö9 "Genel amlamda okul başarılarının yetersiz olmasında geçmiş yaşantılarının da izleri var." demiştir. Derse katılımda yaşanan isteksizliğin bazı nedenlerinin geçmiş yaşantısından kaynaklı sorunlar olableceği öğretmenler tarafindan dile getirilmiştir. Bölünmüş aile yapısı sebebiyle koruma altına alınmış öğrencisi bulunan Ö8 "Bu çocukların derse katılımları az oluyor. Ailelerini düşünüyor olmaları bu durumun nedeni olabilir." diyerek geçmişteki aile bölünmüşlüğü sorunun etkisine dikkat çekmiştir.

Motivasyon koduna bağlı olarak tek bir alt kod oluşmuştur. Pekiştireç kullanma alt kodunda öğretmen; pekiştireçlerin, korunmaya muhtaç çocuk kapsamındaki öğrencilerin, öğrenme öğretme sürecinde yer almalarını sağlama, problem davranışlarını kontrol etme gibi durumlarda yararlandıklarını belirtmiştir. Ö1 "Ödül ve cezayı teşvik amacıyla kullanıyorum. Örneğin ödevini tamamlamadan tenefüse çıkmasına izin vermiyorum. Bu da bir çeşit ceza olmuş oluyor. Örneğin övgü sözleri gibi ikincil tür pekiştireçlerle, bu çocukların problem davranışlarını kontrol altına alıyorum." demiştir. Öğretmenler; örnek davranış gösteren öğrenciyi sınıfça alkışlamışlar, sınıf içinde veya sınıf huzurunda kutlamışlardır. 


\begin{tabular}{|c|c|c|c|}
\hline & & 3: Sosyalleşme İle İlgili Sorunlar & \\
\hline Tema & Kod & Alt Kod & $\mathbf{f}$ \\
\hline \multirow{21}{*}{ 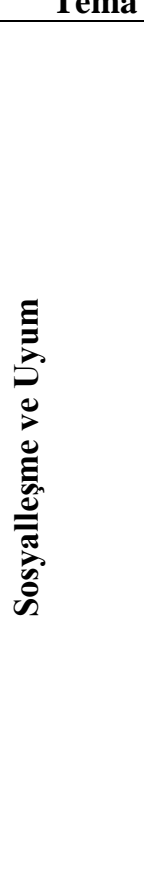 } & \multirow[b]{2}{*}{ Etkinliklere } & Girişimcilik yanlıș anlaşılma & 1 \\
\hline & & Sosyal etkinliklere katılım & 2 \\
\hline & \multirow[t]{4}{*}{ Katılım } & Öğrenme ögretme etkinliklerine katılım & 2 \\
\hline & & Sosyal beceriler & 2 \\
\hline & & Sosyal uyum & 4 \\
\hline & & Duygusal doyum & 1 \\
\hline & Öğretmen & Akran kabulü & 6 \\
\hline & \multirow[t]{4}{*}{ Tutumu } & Veli kabulü & 3 \\
\hline & & Kural иуити & 3 \\
\hline & & Mekânsal akranlık & 2 \\
\hline & & Akran eğitimi & 1 \\
\hline & \multirow{3}{*}{ Hayatilik } & Ruhsal doyum & 3 \\
\hline & & Mekânsal hayatilik & 2 \\
\hline & & Aile özlemi & 7 \\
\hline & \multirow[t]{5}{*}{ Ailesel Sosyallik } & Geçmis yaşantılar & 1 \\
\hline & & Ailesel travmalar & 2 \\
\hline & & Aile ortamı & 2 \\
\hline & & Aile beklentisi & 1 \\
\hline & & Akran yalıtımı & 5 \\
\hline & \multirow{2}{*}{ Yalıtılmışlık } & Ö̆gretmen yalıtımı & 1 \\
\hline & & Çevresel yalttum & 1 \\
\hline
\end{tabular}

Tablo 3'te sosyalleşme ve uyum teması ile ilgili etkinliklere katılıma yönelik öğretmenlerin görüşleri görülmektedir. Sosyalleşme ve uyum temasına bağlı kodlardan birisi de etkinliklere katılımdır. Etkinliklere katılım koduna bağlı olarak oluşan alt kodlar sosyal etkinliklere katılım, öğrenme öğretme etkinliklerine katılım, girişimcilik yanlış anlaşılma ve sosyal becerilerdir.

Girişimcilik yanlış anlaşılma alt kodunda öğretmenler; korunmaya muhtaç çocuk kapsamındaki öğrencilerin, farklı etkinliklere katılım koşunda gösterdikleri arzuyu dile getirmiştir. Bununla beraber olumlu bu görüntünün gerçekte olumsuz bazı halleri perdeleyebildiğini vurgulanmıştır. Ö13 "Bu çocukların etkin oluşu öğretmeni tarafından yanlış değerlendirilebiliyor. Bu etkin oluşun akademik başarının yüksek olacağı olarak görülemez." diyerek öğrencinin girişken olmasının, çeșitli etkinliklere aktif olarak katılmasının bu öğrencinin akademik başarısının doğru orantılı olarak artacağı anlamına gelemeyebileceğine vurgu yapmıştır. Korunmaya muhtaç çocukkapsamındaki öğrencilerin, etkinlik ortamını perdeleyerek, istenmeyen istenmeyen öğrenci davranışları gösterebildikleri ortaya konulmuştur. Bu konuda Ö2 "Sosyal etkinliklere katıliyorlar. Etkinliklere katılma arzusunda. Bu konuda bir sorun bulunmuyor ama sinıf yönetimini olumsuz etkiliyor." demiştir.

Sosyal etkinliklere katılım alt kodunda öğretmenlerin korunmaya muhtaç çocuk kapsamındaki öğrencilerin, sosyal etkinliklere katılımlarına yönelik görüşleri yer verilmiştir. Öğretmenlerin bu konudaki düşünceleri olumlu yöndedir. Ö4 "Gerek öğrenme öğretmeye yönelik gerekse, okul bahçesinde ders dışı, oyun gibi grupsal etkinliklere katılımları oldukça fazladır. Oyunu kurallarına göre oynuyorlar" diyerek öğrencilerin sosyal etkinliklere katılım konsunda görüşünü ortaya koymuştur. Araştırma kapsamında gerçekleşen gözlemlerde de; korunmaya muhtaç çocuk kapsamındaki öğrencilerin, öğrenme öğretme etkinliklerine katılmadıkları, Bu süreçte sıksık ders dış1 nesnelerle ilgilendikleri, öğretmenin ikazıyla derse katılım göstermelerine rağmen derse alakanın saniye ile ifade edilebilecek kısalıkta olduğu gözlemlenmiştir. Bununla beraber, oyun gibi sosyal etkinlikler gerçikleşeceği zaman etkinliklere dikkat ve katılım zamanının fazlalştığı görülmüştür. Sınıf dışında yapılan, çocuk oyunu, futbol oyunu gibi sosyal etkinliklere katılmaya istekli oldukları, etkinliğe katkı sağladıkları gözlemlenmiştir. 
Öğrenme öğretme etkinliklerine katılım alt kodunda öğretmenler; korunmaya muhtaç çocuk kapsamındaki öğrencilerin, öğrenme-öğretme etkinliklerine katılımları hakkındaki görüşleri görüşleri bulunmaktadır. Bu alt koda bağlı olarak öğrencisinin lehine görüş bildiren bir öğretmen bulunmaktadır. Bu konuda Ö4 "Gerek öğrenme öğretmeye gerekse ders dış1 etkinliklerin gerçekleştiği okul bahçesinde arkadaşlarıla birlikte oyun ve etkinliklerine katılım düzeyi fazla. Oyunu kurallarına göre oynuyor." demiştir. Ö4'ün dışındaki öğretmenler bu öğrencilerin, öğrenme ve öğretme etkinliklerine katılımları konusunda görüş belirtmiştir. Yani korunmaya muhtaç çocuk kapsamındaki öğrencilerin öğrenme öğretme etkinliklerine katılımı konusuda yetersizliği vurgulanmıştır. .

Sosyal beceriler alt kodunda öğretmenler; korunmaya muhtaç çocuk kapsamındaki öğrencilerin, sosyal beceriler kapsamındaki problemleri ve gereksinimleri olan eğitimi vurgulamışlardır. Korunmanaya muhtaç öğrencilerin okula başlangıç sürecinde utangaçlık ve çegingenlik göstedikleri ve bu durumun olması gereknden daha fazla sürede devam edebildiği belirtilmiştir. Ö3 bu konuyu "Bu çocuklarda çekingenlik oluyor. Okula başlangıç sürecinde, arkadaşlarıyla iletişimi başlatmakta zorluk yaşıyorlar. Bu sorun sınıf arkadaşlarına göre daha uzun sürebiliyor" şeklinde dile getirmiştir. Bu çocukların sosyal becerilerinin geliştirilmesine yönelik eğitimin önemine vurgu yapılmıştır.

Sosyalleşme ve uyum temasına bağlı olarak oluşan kodlardan biri de sosyal kabul kodudur. Sosyal kabul koduna bağlı olarak akran kabulü, duygusal doyum, sosyal uyum, akran eğitimi, kural uyumu, mekânsal akranlık ve veli kabulü alt kodları oluşmuştur.

Sosyal uyum alt koduna bağlı olarak öğretmenler; korunmaya muhtaç çocuk kapsamındaki öğrencilerin, sosyal uyuma yönelik yaşadıkları sorunları ortaya koymuştur. Uyum sorunlarının, şiddete yönelik davranış gösterilmesine neden olabildiği dile getirilmiştir. Ö4 “ Korunmaya muhtaç çocuk kapsamındaki öğrencimde okula başlangıç sürecinde uyum sorunları görüldü. $\mathrm{Bu}$ sorun aşlangıç sürecinde şiddet davranışlarına dönüştü” demiştir. Ö4'ün bu görüşüne karşın bazı öğretmenler de sosyal uyum konusunda bir sorun yaşanmadığını belirtmiştir.

Duygusal doyum alt kodunda öğretmen; korunmaya muhtaç çocuk kapsamındaki öğrencilerin, sevgi duygusuna duydukları ihtiyaç hakkında düşüncelerini belirtmiştir. Ö2 "Korunmaya muhtaç çocuklarda sevgi ihtiyacı çok ama çok fazla" demiştir.

Akran kabulü alt kodunda öğretmenler; korunmaya muhtaç çocuk kapsamındaki öğrencilerin, arkadaşları tarafından kabul görme veya dışlanma durumlarını dile getirmiştir. $\mathrm{Bu}$ öğrencilerden bazılarının akran kabulü konusunda sorun yaşarken bazılarının da sorun yaşamadığı belirtilmiştir. Ö3 "Sınıf arkadaşları tarafndan dışlanmıyor." Ö16 ise bu konuyla ilgili olarak "Bu çocuklar sınıf arkadaşları tarafından kabul ediliyorlar" diyerek iki farklı öğretmen iki farklı durmu ortaya koymuştur. Öğretmen tutumu akran kabulünde önemli bir etkendir. Ö5 "Korunmaya muhtaç çocuk kapsamındaki öğrencilerim, sınıf arkadaşlarınca seviliyor. Sınıf arkadaşları kendilerine yardım etmeye çalışıyor. Öğretmenin kabulü oranında sınıf arkadaşları bu çocuklanı kabül ediyor" biçiminde açılamıştır. Bununla beraber korunmaya muhtaç çocukların akran kabulü konusunda yaşadıkları problemler de belirtilmiş, bu öğrencilerin dışlanabildikleri de dile getirilmiştir.

Veli kabulü alt kodunda öğretmenler; korunmaya muhtaç çocuk kapsamındaki öğrencilerin, diğer öğrenci verilerinin bu öğrencileri dışlamalarıyla ilgili herhangi bir düşünce dile getirilmemiştir. Hatta velilerin bu çocukları kabul etme eğiliminde oldukları belirtilmiştir. Ö2 "Veliler öğrencilere göre daha kabul edici oluyorlar" diyerek velilerin tutumunu ortaya koymuştur.

Kural uyumu alt kodunda öğretmenler; korunmaya muhtaç çocuk kapsamındaki öğrencilerin, sınıf içi kurallar, oynana oyunlara yönelik kurallar, gibi değerlere uyma durumlarının sonuçlarına vurgu yapmıştır. Kurallara uymanın, arkadaşlarının kabulü üzerinde olumlu bir etkisi görülürken, kural dışı hareket etmenin dışlanma gibi etkilerinin olduğu belirlenmiştir. Ö5 
"Korunmaya muhtaç çocuk kapsamındaki bir öğrencim oyunun kurallarını bilmemesinden dolayı kurallara uymadığından arkadaşları tarafından oyuna alınmıyor" Bu konuda Ö13 "Bu çocuklar problem davranış gösterdiklerinde dışlanabiliyorlar. Öğrenci sorun oluşturmuyorsa kabul görüyor" demiştir.

Mekânsal akranlık alt kodunda öğretmenler; korunmaya muhtaç çocuk kapsamındaki öğrencilerin, okul dışındaki yaşamlarında, sevgi evlerinde barınma, yurtta yaşama, gibi sebeplerle aynı ortamı paylaştıkları kimselerle olan ilişkilerinden ve bu etkileşimin öğrenme-öğretme süreçlerine olumsuz etkisine değinmiştir. Korunmaya muhtaç kapsamındaki çocukların kendi aralarında olumsuz etkileşim oluşturdukları öğretmenlerin ortak görüşüdür. Yaş açısından büyük olan çocukların yasanın kendilerine tanımış olduğu hakların farkında olması nedeniyle yaşça küçük olanları olumsuz yönlendirme yapmaları öğretmenler açısından en önemli sorunlardan birisidir. Çocuklarla alakalı yönetmelik ve yönergeler neredeyse tamamen yalnızca çocukların haklarını düzenlemektedir. Korunmaya muhtaç yasa kapsamındaki çocuğun, kendi davranışının sorumluklarını ve sonuçlarına yönelik düzenlemelerin çok az ya da yetersiz olmasının çocuklarda görülen istenmeyen davranışları etkilediği söylenebilir. Bu kapsamda düşüncesini ortaya koyan öğretmenlerin tamamı olumsuz yöndeki etkileşime vurgu yapmıştır. Olumsuz örnek olma konusuna Ö1 "Korunmaya muhtaç öğrencilerbirbirini olumsuz etkiliyor. Olumsuz örneklerle farkındalık oluşturuyorlar. Size bir şey olmaz. Dersten, okuldan kaçabilirsiniz diyerek olumsuz örnek oluşturuyorlar." şeklinde belirtmiştir. Bu durumundan kaynaklanacak olan akademik başarı yetersizliklerine önlem alınmasının gerektiğine" Ö11 "Akranları (özellikle yuva-yurt ortamı akranları) tarafından kötü örnek olunması akademik başarılarını düşürüyor. Bu nedenle korunmaya muhtaç çocukların barınma ortamlarında seviye grupları oluşturulmalı. Birbirlerini olumsuz etkileyecek etkileşmleri engelleyecek önlemler alınmalı.” diyerek vurgu yapmıştır.

Korunmaya muhtaç çocuk kapsamındaki öğrencilerin, öğrenim gördükleri sınıflarda akranları tarafindan dışlanmadıkları, etkinliğe kabul edildikleri görülmüştür. Korunmaya muhtaç çocuk kapsamındaki öğrenci oyunda kuralları bozma davranışına yöneldiğinde her öğrenciye yaptıkları gibi tepki göstermişlerdir. Korunmaya muhtaç çocuk kapsamında yer alan öğrencilerin arkadaşları tarafından dışlanmadığ 1 gözlemlenmiştir. Bu gözlem, öğretmen görüşleri ile uyumlu görünmektedir.

Korunmaya muhtaç çocuk kapsamındaki öğrencilerin, sınıf arkadaşlarına ve okul içerisindeki diğer arkadaşlarına yönelik, üzerine atlayarak yere devirme, çelme takma, tekme savurma gibi şiddet eylemlerinin olduğu gözlemlenmiştir. Bu eylemler uzun süre ile devam etmemiş, 5-10 saniye kadar bir süre içinde sonlanmış, çocuklarda herhangi bir yaralanma, kavganın devam ettirilmesi gibi istenmeyen sonuçlara yol açmamıştır.

Akran eğitimi alt kodunda öğretmen; korunmaya muhtaç çocuk kapsamındaki öğrencilerin, sosyo-kültürel bağlamda eğitilmelerinde akran eğitiminin yararından söz etmiştir. Ö5 "Sosyokültürel eğitim açısından akran eğitimi daha yararlı oluyor." diyerek bu konuya vurgu yapmıştır.

Korunmaya muhtaç çocuk kapsamındaki öğrenciler, sınıf içi ve sınıf dışı oyun etkinliklerine katıldıklarında, oyun kurallarına uydukları gözlemlenmiştir. $\mathrm{Bu}$ etkinlikler sırasında, diğer arkadaşları tarafından dışlanmamışlardır. Yapılan gözlemle, oyun kurallarına uydukları sürece, tüm öğrencilerin kabul gördüğü, oyun kurallarına uymadıklarında ise tüm öğrencilere, benzer tepkiler gösterildiği, korunmaya muhtaç çocuk kapsamında olmanın, bu durumu etkilemediği sonucuna ulaşılmıştır. Gözlem sonucunda edinilen izlenim, öğretmen ifadelerini desteklemektedir.

Sosyalleşme ve uyum teması ile ilgili hayatilik hakkındaki düşüncelerine yer verilmiştir. $\mathrm{Bu}$ temaya bağlı olarak oluşan kodlardan biri de hayatilik kodudur. Hayatilik koduna bağlı olarak ruhsal doyum ve mekânsal hayatilik, çevresel hayatilik alt kodları oluşmuştur. 
Ruhsal doyum alt koduna bağlı olarak korunmaya muhtaç çocuk kapsamındaki öğrencilerin, sevgi, şefkat, merhamet vb. duygulara duydukları ihtiyaç ortaya konulmuştur. Ayrıca bu çocuklara, acıma duygusunun olumsuz etkilerinin olabildiğine vurgu yapılmıştır. Ö7 "Bu çocukların acınmaya değil; sevgi ve şefkat ihtiyaçları var. Toplum tarafından acındıkları düşüncesi dışlandıklarını da düşündürüyor." diyerek sevgi ve şefkat ihtiyacına vurgu yapmış ve acıma duygusunun getirebileceği bir takım olumsuz sonuçlara işaret etmiştir. Ö6 "Bu çocukların sevgi ihtiyacı daha yoğun. Ruhsal doyuma ihtiyaçları var." ifadesiyle psikolojik bir ihtiyacı ortaya koymuştur.

Mekânsal hayatilik alt kodunda öğretmenler; korunmaya muhtaç çocuk kapsamındaki öğrencilerin, barındıkları kurumsal ortamlarda da sorun yaşayabildiklerinden, bu sorunların nedeninin barındıkları kurumların kendisi olabileceğinini dile getirmiştir. Ö2 "Bu çocuklar, barındıkları yuva-yurt ortamında da sorun yaşıyorlar. Kurumlarında da problem davranışlar gösteriyorlar." Çalışma kapsamında görüşülen öğretmenlerden büyük bir bölümü, çocuk evleri uygulamasının daha yararlı olduğuna dair görüş bildirmiştir. Bu konuda Ö14 "Yuva ve yurt ortamında değil de ev ortamında olduklarında eğitim-öğretim süreçleri ve sosyal ilişkiler açısından daha iyi oluyorlar. Yuva-yurt ortamına geri döndüklerinde bu durum tersine dönüyor ve seviyeleri düşüyor." demiştir.

Ev ortamında bulunan çocukların, yuva ortamında yaşayan çocuklara göre, sosyal ve akademik beceriler konusunda daha iyi oldukları gözlemlenmiştir. Bu gözlem; öğretmenlerin, ev ortamı ile ilgili ifadelerini destekler niteliktedir.

Ev ortamına (Çocuk Evleri Uygulaması) alınacak çocuklar: yaş, cinsiyet, akrabalık bağı vb. kıstaslar ile birlikte; birbirleri ile uyumlu olan, sosyal uyum problemleri ve davranış problemleri göstermeyen çocuklar arasından seçilmektedir. Ev ortamında bulunan çocukların, yuva ortamında yaşayan çocuklara göre, sosyal ve akademik beceriler konusunda daha iyi olma nedenlerinden birinin de, ev ortamına alınmalarında temel alınan bu özellikleri olabileceği düşünülmüştür.

Sosyalleşme ve uyum temasına bağlı olarak oluşan kodlardan biri de ailesel sosyallik kodudur. Ailesel sosyallik koduna bağlı olarak aile özlemi, geçmiş yaşantılar, ailesel travmalar, aile ortamı, aile beklentisi alt kodları oluşmuştur.

Aile özlemi alt kodunda öğretmenler; korunmaya muhtaç çocuk kapsamındaki öğrencilerin, aile ortamına duydukları ihtiyacın eğitim-öğretim hayatına olan yansımalarını ortaya koymuştur.. Ö7 "Bu çocuklarda anne özlemi, baba özlemi var.”. Ö12 “ Anne babanın yerini hiçbir şey dolduramıyor.” Anne baba sevgisini başkalarının sağlayamadığına vurgu yapılmıştır.

Geçmiş yaşantılar alt kodunda öğretmen; korunmaya muhtaç çocuk kapsamındaki öğrencilerin, geçmiş yaşantılarının eğitim-öğretim faaliyetlerine katılımı negatif yönde erkisinin olabildiğine değinmiştir. Ö13 “ Dersin konusu aile ilgili olduğunda üzüldüklerini görüyorum. Derten koparak başka âlemlere dalıyorlar” demiştir.

Ailesel travmalar alt kodunda öğretmenler; korunmaya muhtaç çocuk kapsamındaki öğrencilerin, ebeveynlerinden biri veya her ikisinin kaybı nedeniyle yaşadıkları olumsuz durumlardan bahsetmişlerdir. Ö5 "Bu çocukların temel sorunlarından birisi anne babalarının olmaması." Öğretmenler; anne-babanın, çocuk hayatında yeri başka bir şey ile doldurulamayan unsurlardan olduğunu vurgulamışlardır. Ö14 "Anne baba eksikliğini gidermek çok zor." Öğretmenler; anne-baba yokluğunun önemli bir sorun olduğunu ifade etmiştir.

Aile beklentisi alt koduna bağlı olarak korunmaya muhtaç çocuk kapsamındaki öğrencilerin, ailelerine yeniden kavuşacakları beklentisinden kaynaklanan soruna vurgu yapılmıştır. Korunmaya muhtaç çocuk kapsamında yer alan öğrenciler ebevenlerini kaybetmenin yanısıra aile bölünmüşlüğnden dolayı da bu kapsama alınabilmektedir. Korunmaya muhtaçlık kapsamına girmesine neden olan durumun geçerliliğini yitirmesi halinde, bu çocuklar, tekrar ailesine dönebilmektedir. Aile bölünmüşlüğü sebebiylei korunmaya muhtaç çocuk kapsamına alınmış 
çocukların, bir gün aile bölünmüşlüğünün ortadan kalkacağı beklentisi bulunmaktadır. Ailenin yeniden bira araya gelmesiyle kurum ortamından ayrılacağı beklentisinin olması nedeniyle yaşanan sorunlara vurgu yapılmıştır. Ö11 "Ailesi bölünmüş olan çocuklar aileye kavuşacağ 1 beklentisi içerisinde oluyorlar. Bu da okula uyumlarını olumsuz etkiliyor. Kendilerini bu okulda geçici olarak görüyorlar. Ne de olsa yuva-yurt ortamından, dolayısıyla bu okuldan gideceğim düşüncesi var. Uyum sorunları kendisinden başlayarak arkadaş çevresi, sınıf ortamı, okul ortamı biçiminde sıkıntı olarak ortaya çıkıyor" demiştir.

Aile ortamı alt kodunda korunmaya muhtaç çocuk kapsamındaki öğrencilerin, en önemli ihtiyaçlarından aile ortamının sağlanamadığı belirlenmiştir. Ö13 "Para ile tutulan anne ne kadar anne olabilir?". Ö1 "Yuva-yurt görevlileri çocuğa para için bakıyorlar. Bu da anne baba sevgisinin yerini tutmuyor." Mesleki bir görev olarak yapılan çalışmalarda aile ortamının sağlanamadığına vurgu yapılmıştır.

Sosyalleşme ve uyum temasına bağlı olarak oluşan kodlardan biri de yalıtılmışlık kodudur. Yalıtılmışlık koduna bağlı olarak akran yalıtımı, çevresel yalıtım ve öğretmen yalıtımı alt kodları oluşmuştur.

Akran yalıtımı alt koduna bağlı olarak korunmaya muhtaç çocuk kapsamındaki öğrencilerin, öğrenme öğretme sürecinde yaşadıkları yalıtılmış ortaya konulmuştur. Konuyla ilgili olarak Ö9 "Sınıftaki öğrenciler, bu öğrencileri, korunmaya muhtaç çocuk olduğu için yalıtıyorlar." diyerek korunmaya muhtaç çocuk kapsamındaki öğrencilerin dışlanabildiğini belirtmiştir.

Gözlem amacıyla okullara gidildiğinde, dışlama davranışının alt sınıf sevilerinde olmadığı gözlemlenmiş̧ir. Ancak sınıf seviyesi arttıkça, dışlama davranışı çok az da olsa görülmüştür. Dördüncü sınıf düzeyinde korunmaya muhtaç çocuk kapsamındaki bir öğrenci, okul bahçesindeki oynanan etkinliğe girmek istemiş olmasına rağmen etkinliğe alınmamıştır. Ancak başka bir öğrencinin isteği kabul edilerek oyuna alınmıştır. Öğrencinin oyuna alınmama nedeninin oyun kuralllarına uymamai mızıkçılık yapma olduğu öğrenciler tarafından dile getirilmiştir. Öğrencinin dışlanma nedeninin "Korunmaya muhtaç çocuk" kapsamında olduğu için değildir. Bu öğrencilerin, korunmaya muhtaç çocuk kapsamında olmaları nedeniyle dışlandıkları bir olaya rastlanılmamıştır.

Öğretmen yalıtımı alt kodunda korunmaya muhtaç çocuk kapsamındaki öğrencilerin, öğretmenler ve okul yönetimi tarafindan da okula kabul edilmek istenmeme durumu ortaya konulmuştur. Ö1 "İdare tarafindan da istenmiyorlar." diyerek, bir önceki çevresel yalıtım alt kodunda ortaya konulan görüşleri destekler nitelikte ve bu düşüncelere uyumlu olan düşüncesini belirtmiştir.

Çevresel yalıtım alt koduna bağlı olarak korunmaya muhtaç çocuk kapsamındaki öğrencilerin, eğitimin diğer paydaşları tarafindan da yalıtılabildiğini belirlenmiştir. Ö1 bu konuya ilişkin "Okullarda, genel olarak (öğretmen, öğrenci, veli) istenmiyorlar." demiştir. Öğretmen, bu öğrencilerin, okulun sosyal yapısını oluşturan ve toplumun küçük bir örneklemi de denilebilecek, eğitimin paydaşları yani öğretmenler, öğrenciler ve veliler tarafından istenmiyor oluşlarını dile getirmiştir. 


\begin{tabular}{|c|c|c|c|}
\hline & & blo 4: Problem Davra & \\
\hline Tema & Kod & Alt Kod & $\mathbf{F}$ \\
\hline \multirow{13}{*}{ 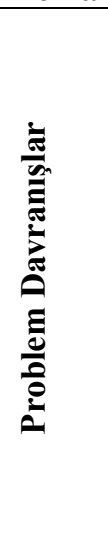 } & \multirow{6}{*}{ İçe Dönük } & Psikoloiik ihtiyac & 4 \\
\hline & & Öğrenilmis caresizlik & 2 \\
\hline & & İcsel denetim & 1 \\
\hline & & Yetersizlik sergileme & 3 \\
\hline & & Kurallara иутата & 5 \\
\hline & & Saldirganlık & 5 \\
\hline & \multirow[t]{6}{*}{ Dışa Dönük } & Güven/ilgi ihtiyacı & 4 \\
\hline & & Istismar & 1 \\
\hline & & Kaçınma & 1 \\
\hline & & Derse katıllm & 3 \\
\hline & & Olumsuz çevresel etki & 1 \\
\hline & & Sorumluluk bilinci & 2 \\
\hline & Motivasyon & Odaklanma & 1 \\
\hline
\end{tabular}

Tablo 4'te problem davranıșlar temasına bağlı olarak oluşan kodlardan biri de içe dönüklük kodudur. İçe dönüklük koduna bağlı olarak öğrenilmiş çaresizlik, psikolojik ihtiyaç, yetersizlik sergileme, kurallara uyma ve içsel denetim alt kodları oluşmuştur.

Psikolojik ihtiyaç alt kodunda öğretmenler; korunmaya muhtaç çocuk kapsamındaki öğrencilerin, problem davranışlarının altında yatan sebeplerden sayılabilecek çeşitli psikolojik sorunlarına ve bunların yansımalarına değinmişlerdir. Ö2 "Bu çocukların, sürekli devam eden bir dikkat eksikliği problemleri var. Derse odaklanmakta zorlanıyorlar.”. Ö5 "Bu öğrencim derste s1k sık uyukluyor. Bu öğrencim, psikiyatrik ilaç kullanıyor. Bu nedenle uyuyor olabilir." Yapılan gözlemlerde de; bir çocukta parmak emme davranışının bulunduğu, bunun yanında, kalem, silgi vb. materyali de ağzının içine götürdüğü gözlemlenmiştir. Bu sırada derse dikkatini veremediği, etkinliklere katılım gösteremediği, derse odaklanamadığı gözlemlenmiştir. Gözlem bulguları, öğretmen görüşlerini desteklemektedir.

Öğrenilmiş çaresizlik alt koduna bağlı olarak korunmaya muhtaç çocuk kapsamındaki öğrencilerin, durumlarından dolayı öğrenilmiş çaresizlik yaşamadığı belirlenmiştir. Ö5 "Bu çocuklarda korunmaya muhtaç olma durumundan dolayı öğrenilmiş çaresizlik gözlemlemedim.”. Ö16 "Bu çocuklarda, örneğin "ben yurt çocuğuyum, ben yapamam..." gibi öğrenilmiş çaresizlik yaşamıor."

İçsel denetim alt koduna bağlı olarak ortaya çıan bir başka durum da korunmaya muhtaç çocuk kapsamındaki öğrencilerin, oto-kontrol konusunda zayıf olmalarıdır. Öğretmen görüşü psikiyatri alanında hem bir rahatsızlık hem de tanı koymada destek alınan olay/belirti olarak değerlendirilebilen impulsitiveye yani dürtüsellik kavramına işaret ettiği söylenebilir. Dürtüsellik ortama uygun olmayan veya aşırı riskli, olgunlaşmamış, iyi planlanmamış ve çoğunlukla istenmeyen sonuçlara yol açan çeşitli davranışları kapsar. Dürtüsellik çok sayıda psikiyatrik bozukluğun çekirdek belirtilerinden biridir (Yazıcı ve Yazıc1, 2010). Öğretmen, bu öğrencilerde, kontrol edilemeyen dürtüler nedeniyle ortaya çıkan ve problem olarak değerlendirilen davranışların varlığından söz etmiştir. Ö12 Bu konuyu "Davranış problemleri var ama çok ciddi sorunlara neden olabilen davranış problemleri çok sık oluşmuyor. Bu çocuklarda oto-kontrol yani kendi davranışının kontrolü son derece zayıf oluyor. Problem davranışlarının önemli bir bölümünde oto-kontrol konusunda yetersiz oldukları, tepkisel/dürtüsel davranış sergiledikleri görülüyor.” Dürtüselliğin etkileme duruunu ortaya koymuştur. 
Yetersizlik sergileme alt koduna bağlı olarak korunmaya muhtaç çocuk kapsamındaki öğrencilerin, derse katılım konusunda yaşadıkları isteksizlik, çekingenlik, derse hazır olmama gibi durumlara ait gözlemler belirtilmiştir. Ö3 bu konuda "Bu çocuklar derse hazırlıklı gelmiyorlar." diyerek, öğrencilerin derse hazırlıklı gelmediklerini belirtmiştir. Ö9 "Bu çocuklar genellikle içine kapanık oluyorlar. Derse katılım konusunda bu nedenle sıkıntı yaşıyor olabilirler." diyerek yetersizlik sergilemeye vurgu yapmıştır. Güven ve Şahin Taşkın (2008) Sosyal Hizmetler ve Çocuk Esirgemeye ait yuvalarda barınan ilköğretim birinci kademe ikinci devre öğrencilerinin durumunu incelemiştir. Korunmaya muhtaç çocuk kapsamındaki öğrencilerin çeşitli nedenlerle aile sevgisinden ve ortamından mahrum kalmalarının sınıf içerisindeki davranışlarını ve derslere katılımlarını zaman zaman olumsuz etkilediğini belirlemiştir. Alay edilme, zorbalığa maruz kalma, dışlanma gibi çekindiklerini ya da utandıkları için birçok öğrencinin sınıf içerisinde derslere etkili olarak katılamadıklarını ifade ettiklerini belirlemişsir.

Korunmaya muhtaç çocuk kapsamındaki öğrencilerin sıklıkla amaçsız, tepkisel/dürtüsel davranışlarda bulundukları gözlemlenmiştir. Örneğin bir öğrenci; sınıfın sol tarafinda en önde bulunan sırasından kalkıp, sınıfın sağ tarafında en arkada bulunan bir arkadaşının sırasına gitmiştir. Burada sıraya oturmuş (başka bir fiil olmaksızın yalnızca oturma davranışı), 4-5 saniye kadar sonra tekrar kalkarak kendi sırasına geçmiştir. Bu öğrencilerin, sınıf içerisinde, yanlarında oturan arkadaşları ile önlerinde ve arkalarında bulunan arkadaşlarının eşyalarını elleme (zarar vermeksizin), alma ve aldığı gibi aynı anda bırakma (merak, inceleme, çalma vb. olmaksızın) şeklinde davranışlar gerçekleştirdikleri gözlemlenmiştir. Öğretmen görüşleri ile gözlem sonuçları uyumlu görünmektedir.

Dışa dönük koduna bağlı olarak saldırganlık, kurallara uymama, güven/ilgi ihtiyacı, kaçınma, istismar, sorumluluk bilinci, olumsuz çevresel etki, derse katılım alt kodları oluşmuştur.

Kurallara uymama alt kodunda öğretmenlerin büyük çoğunluğu, bu öğrencilerde kurallara uymama davranışının bulunduğunu ifade etmişlerdir. Yalnızca bir öğretmen bu konuda problem yaşanmadığını, bir öğretmen de bu problem davranışın tüm korunmaya muhtaç çocuklarda görülmeyebildiğini dile getirmiştir. Ö1 "Akademik başarı genellikle düşük. Bunun temel nedeni disiplinsizlik. Derse girmemek, sınıf kurallarına uymamak, öğretmene başkaldırmak beceri/ başarı olarak görülüyor." diyerek, problem davranışın öğrenci gözüyle nasıl göründüğü konusuna ve akademik başarıya etkisine dikkat çekmiştir. Kurallara uymama davranışının korunmaya muhtaç tüm öğrencilerde görülmeyebildiğine dair Ö8 "Disiplin sorunları çocuktan çocuğa değişebiliyor. Bazı çocuklar sınıf içi kurallara uyarken, bazı çocuklar da kurallara uymayabiliyorlar." demiştir.

Saldırganlık alt kodunda öğretmenler; korunmaya muhtaç çocuk kapsamındaki öğrencilerin, saldırgan davranışlarından ve bu davranışların altında yattığını düşündükleri problemlerden bahsetmişlerdir. Saldırganlık; egemen olmak, yenmek, yönetmek amacıyla güçlü, şiddetli, etkili bir hareket, fiil, işlem: bir işi bozma engelleme, boşa çıkarmaya karşı düşmanca, yaralayıcı, hırpalayıcı veya tahrip edici amaç taşıyan davranış olarak tanımlanır. Öğretmenler, saldırgan davranışların altında yatan sebepleri sevgisizlik ve parçalanmış aileden gelme şeklinde açıklamışlardır. Öğretmenler, saldırgan davranış olarak, bağırma, yere yatma, şiddet içerikli davranış, çelme takma, arkadaşlarına ait eşyayı çekiştirme davranışlarını örnek vermişlerdir. Ö5 "Bu öğrencilerimden birinde bağırma, yere yatma davranışları vardı.”. Bu tip davranışların sık sık tekrarlanabildiği belirtilmiştir. Yapılan gözlemlerde de; korunmaya muhtaç çocuk kapsamında yer alan üç öğrencide saldırganlık davranışı görülmüştür. Bu öğrenciler, arkadaşlarına ait defterleri çekiştirmişler, sayfalarını karıştırmışlar, arkadaşlarına vurmaya çalışmışlar, oturdukları sıra veya masayı sallamışlardır. $\mathrm{Bu}$ öğrencilerden birinin, okul bahçesi içerisinde, teneffüs esnasında, sınıf arkadaşlarından birinin üzerine ve sebepsiz olarak (görünen bir sebep olmaksızın, bir anda) atladığı, arkadaşını yere yıktığı, sonra da hiçbir şey olmamış gibi yürüyüp gittiği gözlemlenmiştir. 
Öğrenme öğretme sürecinde sınıf içi gözlemde de; öğrencinin izin almaksızın sınıf dışına çıktığı görülmüştür. Korunmaya muhtaç çocuk kapsamındaki üç öğrencinin, etkinliklere katılım yerine ders dışı nesnelerle ilgilenmişler, sınıfa, yere çöp atmışlardır. Gözlem sonuçları ile öğretmen görüşlerinin birbirini desteklediği görülmüştür.

Güven/ilgi ihtiyacı alt kodunda, korunmaya muhtaç çocuk kapsamındaki öğrencilerin, güven ve ilgi ve sosyal kabulü istenmeyen davranışlar sergileyek sağlamaya çalıştıklarına değinilmiştir. Bu konuda Ö13 "İlgi çekmek için problem davranış gösteriyorlar. İlgi ihtiyaçlarını bu şekilde karşılamaya çalışıyorlar" diyerek sorunu ortay koymaya çalışmıştır. Çocuk, barındığ kurumdaki danışman öğretmenininden problem davranış konusunda destek bulmayacağını farkettiğinde problem davranıştan vazgeçebilmektedir.

İstismar alt kodunda, korunmaya muhtaç çocuk kapsamındaki öğrencilerin, kendilerine gösterilen sevgiyi istismar ettikleri dile getirilmiştir. Bu görüş, güven ihtiyacı alt kodunda belirtilen özelliklere göre korunmaya muhtaç çocukların, kendilerine destek hissettiklerinde, problem davranışa yöneldikleri geldikleri yargısı ile uyuşmaktadır. Ö9 "Bu çocuklar, kendilerine gösterilen sevgi ve ilgiyi istismar edebiliyor. Öğretmenin kendini sevdiği düşüncesi, ödev yapmama, akran zorbalığı gibi problem davranışları etkileyebiliyor. Öğretmen beni seviyor, bana kızmaz filan dediğini duydum.”. Öğretmen korunmaya muhtaç öğrencilerin sevgi ve ilgi istismarına vurgu yapmıştır.

Kaçınma alt kodunda korunmaya muhtaç çocuk kapsamındaki öğrencilerin, arka sıraya oturmak isteyerek dersten ve öğretmen kontrolünden daha uzak olma isteği olduğu belirtilmiştir. Ö4 "Bu çocuk en arka sırada oturmak istiyor. Böylelikle dersten ve öğretmenden uzaklaşabileceğini düşünüyor. Arka sıraya giderken arkadaşlarını rahatsız ediyor.". Öğrencinin, arkalarda bulunan sırada otutururken sınıf arkadaşlarına rahatsızlık verebilme ihtimali dile getirilmiştir.

Olumsuz çevresel etki alt kodunda öğretmen; korunmaya muhtaç çocuk kapsamındaki öğrencilerin, yaşamsal çevreleriyle olumsuz etkileşimde bulunmasının problem davranışlara neden olduğunu belirtmiştir. Öğretmen, barındıkları yuva, yurt vb. kurumsal ortamlarda etkileşimde bulundukları arkadaşları ve kardeşlerinin olumsuz davranışları bu çocuklar için kötü örnekler oluşturabilmesinin okuldan kaçma gibi problem davranışlara ve akademik başarısızlığa neden olabileceğine vurgu yapmıştır. Bu konuda Ö11 “ Okulda olmayan diğer yuva-yurt ortamı arkadaşları, yuva-yurt ortamından olsun veya olmasın kardeşleri ile birlikte okuldan kaçma eğilimindeler. Çocuk firsatını bulunca bahçe dışında bekleyen ağabeyinin yanına koşarak okuldan kaçıyor. Akranları, özellikle yuva-yurt ortamındaki arkadaşları tarafından olumsuz örnek oluşturulması akademik başarılarının düşmesine neden oluyor. Bu nedenle yuva-yurt ortamında seviye grupları oluşturulmalı. Olumsuz etkileşimleri engelleyecek tedbirler alınmalı." Öğretmen çevresel etkileşimin olumsuz etkisini belirtmiştir.

Derse katılım alt koduna bağlı olarak öğretmenler; Korunmaya muhtaç öğrenme öğretme etkinliklerine katılmada sorun yaşadığını ifade etmiştir. Öğretmenler sorunun nedenlerine yönelik görüş belirtmiştir. Korunmaya muhtaç çocuk kapsamındaki öğrencilerin öğrenme ve öğretme etkinliklerine katılımlarının sınıf ortalamasının da çok altında olabildiği gözlemlenmiştir. Buna karşılık, sınıf içi oyun etkinliklerine katılmaya biraz daha istekli oldukları gözlemlenmiştir.

Sorumluluk bilinci alt kodunda öğretmenler; okul saati dişındaki ders görevlerinin yapılmaması, öğrenme öğretme sürecinin bozulması gibi sınıf arkadaşlarının öğrenme öğretme hakkına sayg1 ve sorumlulukların bu öğrencilerde eksik olabileceğine değinmiştir. Ö1 "Çocuklar verilen ev ödevlerini yapmıyorlar.". Ö11 "Derse kendileri katılmadığı gibi engellemeye yönelik (kötü/istenmeyen yönde) tutum ve davranışlarda bulunuyorlar. Öğrenme öğretme sürecini olumsuz etkiliyorlar.” Öğretmen korunmaya muhtaç çocuk kapsamındaki öğrencilerde sorumluluk bilincinin gelişmediğini belirtmiştir. 
Odaklanma alt kodunda öğretmenler; korunmaya muhtaç çocuk kapsamındaki öğrencilerin, derse dikkatini yoğunlaştırma sıkıntılarının bulunduğunu belirtmişlerdir. Ö2 " Bu çocuklarda, dikkat eksikliği problemi sürekli olarak görülmektedir. Derse dikkatlerini vermede zorlanıyorlar.” diyerek, korunmaya muhtaç çocuk kapsamındaki öğrencilerin odaklanma problemi yaşadıklarını, derse, konuya, ögretmene odaklanamadıklarını ifade etmiştir.

Korunmaya muhtaç çocuk olarak devlet korumasında bulunan öğrencilerin; derslere odaklanamadıkları dikkat sürelerinin oldukça kısa olduğu (ortalama 5-10 saniye kadar) görülmüştür. Dersten kopuşları ile tekrar derse dönme sürecinin oldukça uzun olduğu (200-300 saniye ve daha uzun) gözlemlenmiştir.

\section{Sonuç}

Korunmaya muhtaç öğrencilere yönelik kurumsal veya ailesel desteğin akademik desteğinin yeterli olmadığı belirlenmiştir. Şahin'in (2013), çalışmasında okulda görevli öğretmenlerin öğrenme öğretme sürecinde parçalanmış aileye sahip çocukların aileden akademik, sosyal ve kültürel destek alamadığını tespit etmiştir. Ailesel destek alınamayan öğrencilerin bir bölümü aileden kaynaklı sorunlar nedeniyle koruma altına alınmış olması aile desteğinden yoksun olmalarından ötürü öğrencilerin akademik başarısını etkilediği belirlenmiştir. Korunmaya muhtaç öğrencilerin, «Biz korunmaya muhtaç çocuğuz, kanun bizi koruyor, bize bir şey olmaz» düşüncesiyle etkinliklere katılmayı reddetme eğiliminde oldukları belirlenmiştir. Bu nedenle etkinliklere katılmaya istekli olmadıkları görülmüştür. Buna karşın oyun oynamak gibi sosyal etkinliklere katılmaya istekli olmalarına rağmen oyun düzenini bozmaya yönelimlerinin olduğu belirlenmiştir. Yasal korumanın çocuklar tarafından algılamalrının yanlış olması nedeniyle hem akademik hem de sosyal alanlarda çeşitli sorunlar yaşadıkları görülmüş̧ür. Can'ın (2017) çalışmasında eğitim öğretimle ilgili mevzuattaki yaptırımların ise uygulanmadığı belirlenmiştir. Bu durumun sebebi olarak da üst idareyi, uygulanmaması gerektiği algısını, sorunun öğretmende görülmesini, siyasi kaygıları ve yöneticilerin bilgi yetersizliği neden olarak gösterilmiştir. Güven ve Şahin Taşkın, (2008) çalışmasında, korunmaya muhtaç çocukların duygusal olarak desteklenmesi halinde sosyal ve kültürel gelişme gerçekleştirecekleri için öğrenme öğretme sürecinine olumlu katkı yapacağını tespit etmiştir. Bu bakımdan çalışmanın bulguları desteklenmektedir. Öğretmen tarafından kabül edilen öğrencilerin diğer öğrenciler ve öğrenci velileri tarafından da şartsız kabul ve sosyal kabul edildiği görülmüştür. Korunmaya muhtaç öğrencilerin sadece öğretmen ve arkadaşları tarafindan sosyal kabule ihtiyacı yoktur. Diğer velilerin de şartsız kabulüne ihtiyacı olduğu tespit edilmiştir. Başar vd. (2016) çalışmasında, öğretmen kabülünün çevrenin de kabülünü sağladığı sonucuna ulaşmıştır. Alkan (2014) çalışmasında aile bölünmüşlüğünün çocuğun akademik başarısını geliştirmediğini vurguamıştır. Aile bölünmüşlüğünün akademik, sosyal ve kültürel yönden olumsuz sonuçları olduğu belirlenmiştir.

Korunmaya muhtaç çocukların en ve aile ortamını yaşaması için geliştirilen "Çocuk Evleri" uygulamasının, çocukların sosyal gelişimlerini olumlu etkilediği tespit edilmiştir. Koşay (2013) çalışmasında çocuklar için yuva ve yurt ortamı gibi kurum bünyesindeki bakımının ev ve aile yaşantısına göre sosyal beceri gelişimi açısından daha yetersiz kaldığını tespit etmiştir. Yaşar ve Dağdelen (2013), ev ortamında yaşamını devam ettiren çocukların daha mutlu olmaları nedeniyle kaygılarının azaldığı, güncel yaşamdaki sorunlarla daha iyi mücadele edebildiklerini belirlemiştir. Bu konuda Bernardi, ve Radl (2014) çalışmasında aile bölünmüşlüğü yaşayan çocukların uzun vadedeki sorunlarını incelemiştir. Kısa vadede boşanmanın olumsuz etkisini ortaya koyan çok sayıdaki çalışmaya karşılık boşanmadan kaynaklı uzun süreçteki etkilerini inceleyen çok az sayıda çalışmaya rastlanıldığını belirtmiştir. Boşanmanın yaşamın ilerleyen sürecinde birçok yönüyle olumsuz etkilerinin olduğunu belirlemiştir. Ailelerin eğitim seviyesi yükseldikçe meydana gelen boşanmanın eğitim seviyesi düşük ailelerde meydana gelen boşanmaların olumsuz etkileri dikkate alındığında yıkıcılığının \%12 oranında fazla olduğu sonucuna varmıştır. Aile bölünmüşlüklerinin 
getirdiği psikolojik, sosyal ve kültürel travmalar akademik yaşamı ve başarıyı olumsuz etkileyebilmektedir. Razon (2007) çalışmasında duygusl sorunların bireyin akademik yaşantısını etkilediğini belirtmiştir.

Korunmaya muhtaç çocukların, öğrenme öğretme sürecinde etkinliklere katılma, fikir ve düşüncelerini söylemede yeterince etkin olamadıkları gözlemlenmiştir. Koşay (2013) çalışmasında benzer sonuca ulaşmıştır. Korunmaya muhtaç çocukların sosyal becerilerinin, bu kapsamda olmayan aile içinde yaşayan çocuklara göre daha düşük olduğunu belirlemiş, bu kapsamda sosyal beceri eğitimi çalışmalarının yapılmasının bu çocuklar için yararlı olabileceğini belirtmiştir. Şentürk (2012) Sosyal, kültürel ve bilișsel olarak desteklenmeyen öğrencilerin okul başarısının düștügünü belirlemiştir. Aile desteğinin çocukların hem akademik hem de sosyal yaşamında önemli olduğu görülmüştür.

Korunmaya muhtaç çocuklar kanunun korumacılığı nedeniyle özellikle dışa dönük problem davranışlara yönelmektedir. Bu kapsamda çocuklar okul ve sınıf düzenini bozma, öğrenme öğretmeyi engelleme ve istediği zaman okuldan kaçma gibi dışa dönük problem davranışlarda bulundukları belirlenmiştir. Yasal korumanın öğrenciler tarafından istismar edildiği akademik duyarsızlığa neden olduğu sonucuna varılmıştır. Bu davranışlar korunmaya muhtaç çocuklarla birlikte tüm sınıfı etkileyebilmektedir. Bu konuda İpek (2010), çalışmasında araştırmanın bulgularını destekleyen sonuca ulaşmıştır. Korunmaya muhtaç çocukların akademik başarısının düşük olduğunu, okulu önemsemeyerek okuldan kaçma gibi problem davranışların diğer çocuklara göre daha fazla olduğunu belirlemiştir. Buna bağlı olarak da 12 yıla çıkarılan zorunlu eğitimden ayrılma durumlarının bu kapsamda olmayan öğrencilere göre daha yüksek olduğunu tespit etmiștir. Yaşanan bu soruna yönelik çözüm üretebilmek için ilgili paydaşların öğrencilerin öğrenim gördüğü okul yönetimi ve görevli öğretmenlerle işbirliği içerisinde olmasının yararlı olabileceği önerisini getirmiştir.

Yasal mevzuaatta tanımlanmadığı için devlet güvencesinde yer alan, çocuklar özel gereksinimli olarak tanımlanmamaktadır. özel ihtiyacı olan çocuk olarak değerlendirilmemektedir. $\mathrm{Bu}$ nedenle, özellikle, yurt, yuva, çocuk evi vb. hizmetlerin verildiği bölgede yer alan okul çevresinde, bu çocuklar sınıf mevcudunda önemli bir yer tutmaya başlamıştır. Bu durum da, okul ve sınıf içerisinde, problemli öğrenci sayısını arttırabilir. Özel Eğitim Hizmetleri Yönetmeliği özel gereksinimli öğrenci sayısının sınıflarda nasıl bulunacağını belirlemiştir. Bu durum da öğrencilerin öğrenme öğretme sürecini etkileyebilmektedir. Goldson'a göre (2000), risk altındaki (korunma ihtiyacı olan) çocuklar öğrenme öğretme sürecini yani eğitim öğretim sürecini erken yaşlarda terk etmektedir. Bu çocukların eğitim çağını sonuna kadar tamamlayabilme oranının $\% 2$ belirtmiştir.

Korunmaya muhtaç çocukların kanunun kendilerine sağladığı koruyuculuk sağlaması nedeniyle akademik başarı kaygısı taşımadıkları, duygusal desteğin yeterince sağlanamaması nedeniyle öğrenme öğretme sürecinde problem davranışlara yöneldikleri sonucuna ulaşılmıştır.

\section{Öneriler}

Araştırma Sonuçlarına Yönelik Öneriler

1. Korunmaya muhtaç çocukların sosyal kabul ve uyumunu gerçekleştirilecek sosyal, kültürel etkinlikler gerçekleştirilebilir.

2. Kanunların sağladığı koruyuculuk nedeniyle akademik yaşantı önemsenmemektedir. Kanunların sağladığı koruyuculukla ilgili hakların elde edilmesiyle ilgili mevzuaat yeniden değerlendirilebilir.

3. Korunmaya muhtaç çocuklar ve sorunları konusunda aileleri ve toplumu bilgilendirmeye yönelik kamu spotları hazırlanabilir 
4. Korunmaya muhtaç çocuklarda görülen problem davranışlar ve bu davranışların etkisi konusunda farklı kurumların katılımıyla bir çalıştay düzenlenebilir.

5. Korunmaya muhtaç çocuklarla ilgili öğretmenlerin konuyla ilgili mevzaattaki bilgi eksikleriklerini gidermek ve kurumlar arası iletişimin güçlenmesi için seminer düzenlenebilir.

6. Bu kurumlarda yetişmiş toplumda saygınlığ yapması sağlanabilir

Araştırmacılara Yönelik Öneriler yapılabilir.

1. İlkokul kademesine yönelik yapılan bu çalışma farklı öğretim kademelerinde de

2. Çalışma farklı illerde de yapılarak araştırma sonuçları karşılaştırılabilir

3. Çalışma farklı yöntemler kullanılarak yapılabilir

\section{Kaynakça}

Aile ve sosyal politikalar bakanlığı 2016 y1lı faaliyet raporu. (2017). http://sgb.aile.gov.tr/data/5434f307369dc31d48e42dc5/2016_Faaliyet_Raporu.pdf adresinden 4 Nisan 2017 tarihinde alınmıştır.

Alkan, E. Ö. (2014). Parçalanmış Aile Modelindeki Öğrencilerin Başarı Durumları (Trabzon Örneği). Yayınlanmamış yüksek lisans tezi, Malatya İnönü Üniversitesi, Sosyal Bilimler Enstitüsü.

Başar, M., Doğan, M C., Karasu, M., Şener, N. (2016). Hiperaktif öğrencilerin öğrenme öğretme sürecindeki sorunlarının okuma eğilimlerine etkisi, Turkish Studies, 11(3), 443-464

Bernardi F., Radl J. (2014). The long-term consequences of parental divorce for children's educational attainment. Demographic Research 30 (61), 1653-1680

Büyüköztürk, Ş., Çakmak, E. K., Akgün, Ö. E., Karadeniz, Ş. \& Demirel, F. (2011). Bilimsel Araştırma Yöntemleri (10. Bask1). Pegem Yayıncılık.

Can, N. (2017). Disiplin sorunları ve sınıf yönetimine ilişkin öğretmen ve yönetici görüssleri. Kahramanmaraş Sütçü İmam Üniversitesi Eğitim Dergisi. 38-58

Çocuk Adalet Sisteminin Uygulanması Hakkında Asgari Standart Kurallar (Pekin (Beijing) Kurallart). Kasim 1985.

Çocuk Haklarına Dair Sözleşme (Uluslar Arası Sözleşme, Kasım 1989), Resmi Gazete, 22184, Ocak 1995.

Çocuk Koruma Kanunu (5395 S.K.), Resmi Gazete, 25876, Temmuz 2005.

Goldson, B. (2000). Children in need'or 'young offenders'? Hardening ideology, organizational change and new challenges for social work with children in trouble. University of Liverpool Department of Sociology, Social Policy and Social Work Studies Child and Family Social Work journal. 5, 255-265

Güven, S. Şahin Taşkın, Ç. (2008). Sosyal hizmetler ve çocuk esirgeme kurumuna ait yuvalarda barınan ilköğretim öğrencilerinin sosyal bilgiler derslerine katılımı. Kuram ve Uygulamada Eğitim Bilimleri Dergisi 8(3),925-961 
Korunmaya Muhtaç Öğrencilerin Öğrenme ve Öğretme Sürecinde Karşılaştıkları Sorunların...1559

İpek, A., (2010). Suça Sürüklenen Çocukların Okul Dönemlerinin İncelenmesi Ve Bu Dönemde Barındırdıkları Risk Faktörlerinin Belirlenmesi. Yayınlanmamış yüksek lisans tezi, Ankara Kara Harp Okulu, Savunma Bilimleri Enstitüsü.

Karasar, N. (2011). Bilimsel Araştırma Yöntemi. (22. Baskı) Nobel Yayınları.

King, W. R. \& He, J. (2005). Understanding the role and methods of meta-analysis in IS research. Communications of the Association for Information Systems, 16, 664-687.

Koşay A. (2013). Çocuk Yuvasında Ve Çocuk Evinde Kalan Korunmaya muhtaç çocuklar İle Ailesi Yanında Yaşayan Çocukların Sosyal Becerilerinin Karşılaş̧ııılması, Yayınlanmamış yüksek lisans tezi, İzmir Dokuz Eylül Üniversitesi, Eğitim Bilimleri Enstitüsü.

Milli Ĕ̆itim Bakanlı̆̆ı Okul Öncesi Ë̆itim ve İlköğretim Kurumları Yönetmeliği, (29072 R.G.) 2014

Milli Eğitim Temel Kanunu (1739 S.K.), Resmi Gazete, 14574, Haziran 1973.

Özel Ĕ̈itim Hizmetleri Yönetmeliği, (30471 R.G.) 2018.

Sosyal Hizmetler Kanunu (2828 S.K.), Resmi Gazete, 18059, May1s 1983.

Sosyal Hizmetler ve Çocuk Esirgeme Kurumu Çocuk Yuvaları Yönetmeliği, (23576 R.G.) 1999.

Sosyal Hizmetler ve Çocuk Esirgeme Kurumu Genel Müdürlüğ̈̈ Çocuk Evleri Çalışma Usul ve Esasları Hakkinda Yönetmelik, (27015 R.G.) 2008.

Sosyal Hizmetler ve Çocuk Esirgeme Kurumu Yetiştirme Yurtlarının Kuruluş ve İşleyişine İlişkin Yönetmelik, (22462 R.G.) 1995.

Şahin, Z. D. (2013). Parçalanmış Aileye Sahip Çocukların Eğitiminde Sinıf Öğretmenlerinin Karşılaştığ Problemlerin Belirlenmesi. Yayınlanmamış yüksek lisans tezi, Trabzon Karadeniz Teknik Üniversitesi, Sosyal Bilimler Enstitüsü.

Şentürk, Ü. (2012). Parçalanmış Aile Çocuklarının Eğitimdeki Başarı/Başarısızlık Durumu (Malatya Örneği 2006). Sosyal Politika Çalışmaları Dergisi, 7(29), 105-126.

TÜİK, (2019). Haber Bülteni. (2018, Aralı http://www.tuik.gov.tr/PreHaberBultenleri.do?id=30709 adresinden 4 Nisan 2019 tarihinde alınmıştır.

TÜIKK, (2019). Öğretim y1lı ve eğitim seviyesine göre okullaşma oranı. (2018, Aralık 31). http://tuik.gov.tr/PreIstatistikTablo.do?istab_id=2806 adresinden 4 Nisan 2019 tarihinde alınmıştır.

Türk Ceza Kanunu, (5237 S.K.), Resmi Gazete, 25611, Eylül 2004.

Türk Dil Kurumu, Bilim ve Sanat Terimleri Sözlüğ̈̈, 2019 http://sozluk.gov.tr/ adresinden 4 Nisan 2019 tarihinde alınmıştır.

Uçuş, Ş. (2016). Dezavantajlı çocukların velilerine uygun olarak hazırlanan aile katılım etkinliklerinin (AKE) değerlendirilmesi (Nallıhan Örneği). e-Uluslararast Ĕgitim Araştırmaları Dergisi 7(1), 1-20

Webbink, D., Oosterbeek, H., Lindahl, M., \& Leuven, E. (2004) The effect of extra funding for disadvantaged pupils on achievement. Review of Economics and Statistics Journal.89 (4), $721-736$

Yalçın, A. (2011). Çocuk Koruma Kanunu Kapsamında Korunmaya Muhtaç Çocukların Gelecek Kaygılarının İncelenmesi (Afyonkarahisar Örneği). Yayınlanmamış yüksek lisans tezi, Afyonkarahisar Afyon Kocatepe Üniversitesi, Sosyal Bilimler Enstitüsü. 
Yaşar, Ö. Dağdelen N. (2013). Korunmaya muhtaç çocukların yetiştirilmesinde çocuk yurtlarından çocuk evlerine geçişin çocukların sosyo-kültürel ve psikolojik gelişimlerine etkisi üzerine bir çalışma: Isparta örneği, SDÜ Sosyal Bilimler Enstitüsü Dergisi. 18, 199-221

Yazıc1, K., Yazıcı, A. E. (2010) Dürtüselliğin Nöroanatomik ve Nörokimyasal Temelleri. Psikiyatride Güncel Yaklaşımlar Dergisi, 2(2), 254-280.

Yıldırım, A., Şimşek, H. (2016). Sosyal Bilimlerde Nitel Araştırma Yöntemleri. (10. Baskı). Seçkin Yayınları. 